\title{
A PHYSIOLOGICAL STUDY OF TWO STRAINS OF FUSARIUM IN THEIR CAUSAL RE- LATION TO TUBER ROT AND WILT OF POTATO
}

\author{
A DISSERTATION
}

SUBMTTTED TO THE FACULTY OF THE OGDEN GRADUATE SCHOOL

OF SCIENCE IN CANDIDACY FOR THE DEGREE

OF DOCTOR OF PHILOSOPHY

(DEPARTMENT OF BOTANY)

BY

GEORGE KONRAD KARL LINK

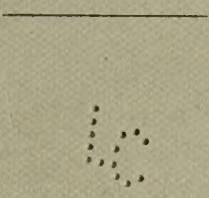

A Private Edition

Distributed by

The University of Chicago Libraries

Reprinted from

The Botanical GazetTe, Vol. LXII, No. 3

Published by

The University of Chicago Press

Chicago, Illinois 
) 


\section{A PHYSIOLOGICAL STUDY OF TWO STRAINS OF FUSARIUM IN THEIR CAUSAL RE- LATION TO TUBER ROT AND WILT OF POTATO}

A DISSERTATION

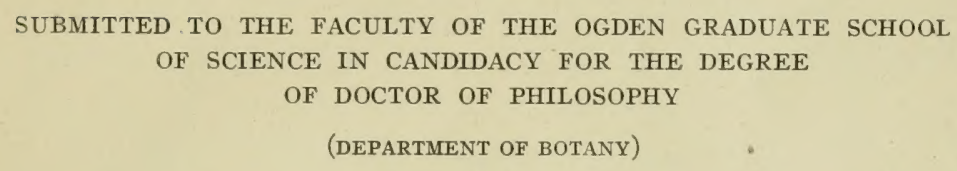

\section{A Private Edition}

Distributed by

The University of Chicago Libraries

Reprinted from

The Botanical Gazette, Vol. LXII, No. 3

Published by

The University of Chicago Press

Chicago, Illinois

\section{$[1916]$}




$$
{ }^{5 B^{60^{8}}}
$$

cists

The Unisersit

אoy 271918

$\therefore \vdots$ 


\title{
T H E
}

\section{Botanical Gazette}

SEPTEMBER I9I6

\author{
A PHYSIOLOGICAL STUDY OF TWO STRAINS OF \\ FUSARIUM IN THEIR CAUSAL RELATION TO \\ TUBER ROT AND WILT OF POTATO
}

CONTRIBUTIONS FROM THE HULL BOTANICAL LABORATORY $219^{\text {I }}$

GEORGE K. K. LINK

(WITH THIRTEEN FIGURES)

There is little doubt among phytopathologists that members of the genus Fusarium play an important rôle in producing diseased conditions in many plants, both wild and cultivated. According to Wollenweber (4I), Fusarium spp. produce wilt in members of the following families: Liliaceae, Bromeliaceae, Musaceae, Solanaceae, Convolvulaceae, Leguminosae, Malvaceae, Linaceae, Cucurbitaceae, Cruciferae, Compositae, Araliaceae, Caryophyllaceae, and Pedaliaceae.

\section{History}

The genus Fusarium was established by $\operatorname{Link}(\mathbf{2 0}, \mathbf{2 1})$ in I809, and Fusarium species were reported on rotted and ring-discolored tubers by Martius in I842, HaRtig in I846, and Schacht in I856. Pizzigoni (29) and Wehmer $(38,39)$ demonstrated by experimental inoculation that Fusarium species can bring about tuber rot. They referred to the Fusarium in question as $F$. solani. Others, however, among them FrANK (II, I2) repeating their work, obtained negative results so far as Fusarium species were concerned; while De BARy (6) and many others regarded the Fusarium spp. as nothing more than obligate saprophytes.

${ }^{x}$ In cooperation with the Nebraska Agricultural Experiment Station. 
The credit of first demonstrating experimentally the relation of Fusarium spp. to certain plant wilts belongs to Sмгтн (34), who found a Fusarium responsible for watermelon wilt. SмIтн and Swingle (35) reported a potato wilt and tuber rot which they considered due to a Fusarium which they called $F$. oxysporum. They considered this organism identical with $F$. solani of PizzigonI and WeHmer, and used the oldest name available, $F$. oxysporum (SCHLEChtENDAHL, I824); however, they reported no experimental inoculations. Pethybridge and Bowers (28) reported a dry rot due to $F$. solani, and Longman (22) also reported a dry rot due to a Fusarium.

Many pathologists and mycologists entertained considerable doubt as to the parasitic nature of Fusarium spp., while others were quite convinced of their parasitic nature. SORAUER (36) was quite positive in his decision, while MASSEE (25) wavered. Lindau (I8) remained skeptical and referred to the $F$. oxysporum of Sмгтн and Swingle as a "Mischart." Duggar (го) was quite positive in his decision. Much of this difference of opinion undoubtedly was due to the confusion that prevailed as to the status of $F$. solani, $F$. oxysporum, and the genus in general, since no basis for extended morphological study of the genus had been established, and even the genus itself had not been sharply defined. MAssee (25) considered $F$. solani to be the conidial form of Nectria solani; while ReInke and BERTHOLDT (30) considered it the conidial form of Hypomyces solani. LounsBury $(\mathbf{2 3})$ tried to arbitrate the matter by suggesting that $F$. solani and $F$. oxysporum are one and the conidial stage of Nectria solani. Appel and Wollenweber (5) published a monograph in which they defined the genus and brought some order into the chaos of species. Among other radical changes they dropped $F$. oxysporum and established $F$. orthoceras in its place.

Manns (24) demonstrated by experimental inoculation that a Fusarium, which he designated (following SMith and Swingle) as $F$. oxysporum, could produce tuber rot and wilt. He made no morphological studies, however, and undoubtedly had not had access to APPEL and WOLLENWEBER's monograph.

JAMIESON and Wollenweber (I6) published an account of a dry rot of tubers induced by a Fusarium which they described as a 
new species (F.trichothecioides Wr.). They refer to it as "a wound parasite capable of destroying potato tubers" and say "this disease is clearly differentiated from the wilt and dry rot ascribed by SмIтH and SwINGLe to F. oxysporum."

Later, the writer (I9) submitted his studies of a dry rot occurring among Nebraska potatoes as a thesis to the Graduate Faculty of the University of Nebraska. The work was done at the request of Dr. E. MEAD Wilcox, and consisted in part of a study of the morphology of a Fusarium that had been isolated from dry rotted tubers in 1908 by Miss Venus W. Pool from potatoes that farmers had sent in from throughout the state during the season I907-I908. Miss PooL established the causal relation of this Fusarium to the dry rot by experimental infection, and named the organism in manuscript $F$. pulverulentum, because of its powdery habit of growth. Both field and laboratory work were carried on for several years, and it was found that this organism caused primarily a dry rot of the tuber, and that it was not the $F$. oxysporum of SмiтH and SwINGLE, a culture of $F$. oxysporum having been furnished the laboratory for comparative work through the courtesy of Dr. SмIтн. The results were to have been published in IgII, and the organism was to be named $F$. pulverulentum, but upon the appearance of APPEL and Wollenweber's monograph Dr. WiLcox proposed to the writer that he reinvestigate the organism along the lines suggested by these authors. This was especially desirable since $F$. oxysporum had been dropped and several new species established. Not only was this carried out, but the whole etiology was gone over again and all of Miss PooL's results verified. It was found that Appel and Wollenweber (5) had not described the species, and consequently it was described as $F$. tuberivorum Wilcox and Link (40). It was so named because of the apparent restriction of its activity to tubers.

A comparison of this paper and the paper of JAMIESON and Wollenweber (I6) made it seem quite likely that both were dealing with the same organism. The organism was isolated in the Washington laboratories from potatoes sent in from Washington, Nebraska, and other states in I9Io, and WoLLENWEBER upon his arrival in the laboratory, using his monograph as the basis, described 
it as a new species. He told the writer in 1913 that he felt convinced that we had described one and the same thing. Comparative studies made by the writer during the past year verify this point of view, and since the Nebraska publication by WiLcox, Link, and Pool (40) did not appear in print until I9I3, the name $F$. trichothecioides should be adopted.

Wollenweber $(4 \mathrm{I}, 42)$ published a further paper in which he categorized the Fusarium spp. very sharply, dividing the genus into sections on the basis of physiological (that is, pathogenicity) and morphological (that is, conidia and chlamydospores) characters. $F$.oxysporum was again established and taken as the representative of the section Elegans, which comprises vascular parasites; and $F$. trichothecioides was put into the section Discolor, which comprises parenchyma destroyers. He distinguished sharply between these and also between the vascular ring-discoloring Fusarium species of section Elegans and the tuber-rotting Fusarium species of sections Discolor, Gibbosum, Martiella, etc.

Referring to the papers by Smith and Swingle (35), Manns (24), and others, particularly to that by Manns, he writes: "They do not separate fusarioses causing tuber rot from those causing both the wilt diseases of the plant and ring discoloration of the tuber, so that the reader might conclude that both wilt disease and tuber rot are caused by the same organism." Referring to his own experiments, he writes: "It also brings out the striking fact that the fungus, a typical xylem inhabitant, does not entirely destroy the tuber without the help of tuber rot Fusarium or bacteria," and "the fact that $F$. oxysporum causes the wilt of growing potato plants and only uses the xylem of the stem end of tubers for over-wintering, without producing a rot of the parenchyma, leads to interesting comparisons with the following 4 species which are able to destroy the tuber entirely from artificial wounds, namely, $F$. coeruleum (Lib.), F. trichothecioides Wr.," etc., and finally "the fact that the latter (F. oxysporum) cannot produce a tuber rot gives a biological contrast to the wound parasites of the tuber, and the fact that they cause the wilt disease of the growing plant presents a contrast to the saprophytes." 


\section{Problem and method of attack}

In the spring and summer of I9I4 the writer discussed the Fusarium situation as outlined by WoLlenweBer with Dr. E. M. Wilcox and Dr. William Crocker. The former suggested that the whole situation ought to be gone over, and the latter that it would be of interest to search for the physiological basis of this alleged biological contrast. It is clear that, if the strict categories of Wollenweber exist, then potato parenchyma must possess either an absolute or an effective immunity toward Fusarium spp. of the Elegans section, and that Fusarium spp. of the Discolor section are either absolutely or practically unable to produce vascular mycoses or wilts.

The purpose of this research was twofold: (I) to determine whether such a sharp biological contrast exists; and (2) to determine what is the physiological basis for such a contrast. Experimental infections of potato plants and tubers were used for the first phase of the problem. It was clear that the second phase might involve a great many considerations, such as the structural, compositional, and metabolic nature of both host and parasite, as well as the relation of environmental factors to these. The important rôle played by the structural and compositional peculiarities of the potato and the influence of external factors upon these is well illustrated by the studies of APPeL and $\operatorname{KrEITZ}(\mathbf{I}, 3)$ on the efficacy of the cork layer in checking bacterial invasions of the tuber. Considerations of time and equipment limitations made it obligatory that the scope of the work be limited to a study of a few representative strains of the groups.

The writer is under obligation to the Departments of Agricultural Chemistry, Horticulture, and Experimental Agronomy of the University of Nebraska Experiment Station for the use of materials and equipment; to Miss Ethel Beaty for help in much of the laborious routine; to Dr. FLORENCE A. MCCORMICK for valuable help in the anatomical and microtechnical phases of the problem; and to Mr. R. A. DAwson for help in preparing the photographs.

The writer decided to work with $F$. oxysporum as representative of the vascular parasite section (ELEgANS), and with 
$F$. trichothecioides or $F$. tuberivorum as representative of the parenchyma-invading section (DISCOLOR). Since it was desirable that the identity of the organisms be well established, the writer asked Mr. W. A. ORton, in whose laboratories Dr. Wollenweber had carried out his recent work, for cultures of the organisms. It was impossible to get cultures which had been authenticated by Dr. WOLLENWEBER, since he had gone to war, but through the courtesy of Mr. Orton, Mr. Carpenter (Dr. Wollenweber's assistant) furnished a strain of $F$. trichothecioides (no. 4I, I9I6) and a strain of $F$. oxysporum (no. 3345A). The other strains of $F$. trichothecioides used had been isolated by the writer in IgrI, and were described as $F$. tuberivorum. Several strains of $F$. oxysporum isolated from Nebraska potatoes were also used.

Pure cultures of these organisms were maintained on sterilized rice in plugged Erlenmeyer flasks, and these were used as a point of departure for all the work recorded.

\section{Infection experiments}

(I) EXPERIMENTAL INFECTION OF TUBERS

Tubers of the Early Ohio and Red Cobbler varieties were used in these experiments. Only sound tubers were selected, and these were thoroughly cleansed and sterilized before infection. At first they were sterilized by the formaldehyde gas method recommended by Wollenweber (4I). Several difficulties were encountered in using this method. It was found very difficult to remove the last traces of the gas without contaminating the chamber, and the tubers often showed the characteristic formaldehyde vapor injuries that have been discussed in bulletins of the New York Experiment Station (13, 37). Consequently, the writer abandoned the first method and sterilized tubers by immersing in $\mathrm{I}$ : Ioo० $\mathrm{HgCl}_{2}$ solution for 1.5 hours. Inoculation was carried out by removing a piece of the cortex with a sterile cork borer, placing an infected grain of rice into the hole, and then replacing the piece of tuber tissue. The wound was then sealed with sterile grafting wax and the tuber placed into sterile chambers. This proved an efficient and convenient way of carrying out the great number of experimental inoculations made. 
The first inoculations were made in December I9I4. The cut ends of 20 Early Ohio tubers were wetted with spore suspensions of $F$. trichothecioides and 5 tubers were kept as controls. Four inoculated and one control potato were kept in each compartment at a temperature of $25^{\circ} \mathrm{C}$. in an almost saturated atmosphere. After 4 weeks all of the inoculated tubers were in advanced stages of rot.

On January 3 I, 3 potatoes were inoculated according to the second method with $F$. oxysporum, and 3 with $F$. trichothecioides, and kept at $20^{\circ} \mathrm{C}$. until February $\mathrm{I} 7$. Two of the former set were slightly rotted and one totally, while the entire latter set was rotted severely. The controls showed no rot (fig. I).

On January I 5 another series was started which was kept at a temperature ranging from $15^{-20^{\circ}} \mathrm{C}$. until February $\mathrm{I}_{5}$. Six sets of 3 tubers each were started and each set was kept in a separate sterile chamber, 2 tubers of each set being inoculated by smearing cut surfaces with agar grown inoculum. Sets I, II, and III were inoculated with $F$. oxysporum, and sets IV, V, and VI with $F$. trichothecioides. In set I, one inoculated tuber was rotted, while the other and the control were sound; in set II, one was deeply rotted and the others sound; in set III, one was deeply rotted and the others sound; in set IV, two were rotted and the control sound; in set $\mathrm{V}$, two tubers were rotted slightly and the control sound; and in set VI, two tubers were rotted and the control sound.

$F$. oxysporum and $F$. trichothecioides were re-isolated from these rotted tubers by placing tissue cut from such tubers on plated glucose agar. Nothing other than the organism with which the tuber had been inoculated developed. Inoculum from these plates was used in infecting tubers again with the same results.

Since these results were at variance with the statements of WOLLENWEBER the experiments were repeated with hundreds of tubers, and the results were verified.

Discussion.-Tubers inoculated with $F$. oxysporum did not develop the ring discoloration that is considered characteristic of the activity of $F$. oxysporum, but a general rot of the whole tuber. Generally, however, this was not a dry rot, but a rot that resembles more the soft rots of bacterial origin, although it is not accompanied 
by the offensive odors of bacterial rots, producing a blackening and softening of tissue which extends a considerable distance beyond the actual site of the organism. This was demonstrated microscopically and culturally. At times, however, especially in cold, dry conditions, a dry rot as typical as that produced by $F$. trichothecioides was produced. F. trichothecioides invariably produced a dry rot with only a very limited darkened zone extending beyond the destroyed zone, made up of large cavities and a mixture of disintegrated, dry, shrivelled tissue and fungus tissue. No darkening extended beyond the actual site of the fungus and no softening of tissue occurred. Microscopic examination revealed the fact that $F$. trichothecioides attacked the tissue intracellularly and destroyed each cell completely before it proceeded to the neighboring cell, while $F$. oxysportm attacked the tissue intercellularly at first, and then attacked the cells intracellularly, but not until the tissue had been blackened and disorganized. In this way a softened tissue without cavities was produced. These rots produced experimentally with pure cultures of $F$. oxysportm lend support to the observations and conclusions of SMith and Swingle (35), Manns (24), who reports the occasional appearance of black specks in the parenchyma of tubers infected with $F$. oxysporum, and JoNES (I7), who attributes stem end rot of tubers to the activity of this organism, although they may have dealt with "Mischarten." SherbakofF (33) reports certain strains of species of Elegans (using the section as a morphological group) to be tuber rotters. He distinguishes between Fusarium spp. that are tuber rotters and such as are vascular element inhabitants. ${ }^{\text {I }}$

\section{(2) EXPERIMENTAL INFECTION OF LIVING PLANTS}

A series of experimental inoculations of healthy potato plants with $F$. oxysporum and $F$. trichothecioides were carried out, in an attempt to determine whether or not $F$. trichothecioides is unable to

${ }^{I}$ After these experiments had been concluded and this paper written, a paper by CARPENTER (7) has appeared. This represents a wholly independent although simultaneously conducted piece of work. The results of CARPENTER make it quite probable that the observations made by the writer on a few strains of $F$. oxysporum are of quite general application, since he arrives at the same conclusions for numerous though different strains of $F$. oxysporum. His conclusions as to the method of attack by the fungus and the nature of the rot are practically identical with the writer's. 
produce wilt, or whether the potato plant enjoys an effective or practical immunity rather than an absolute one. Even though WOLLENWEBER (4I) did not consider $F$. trichothecioides a wilt
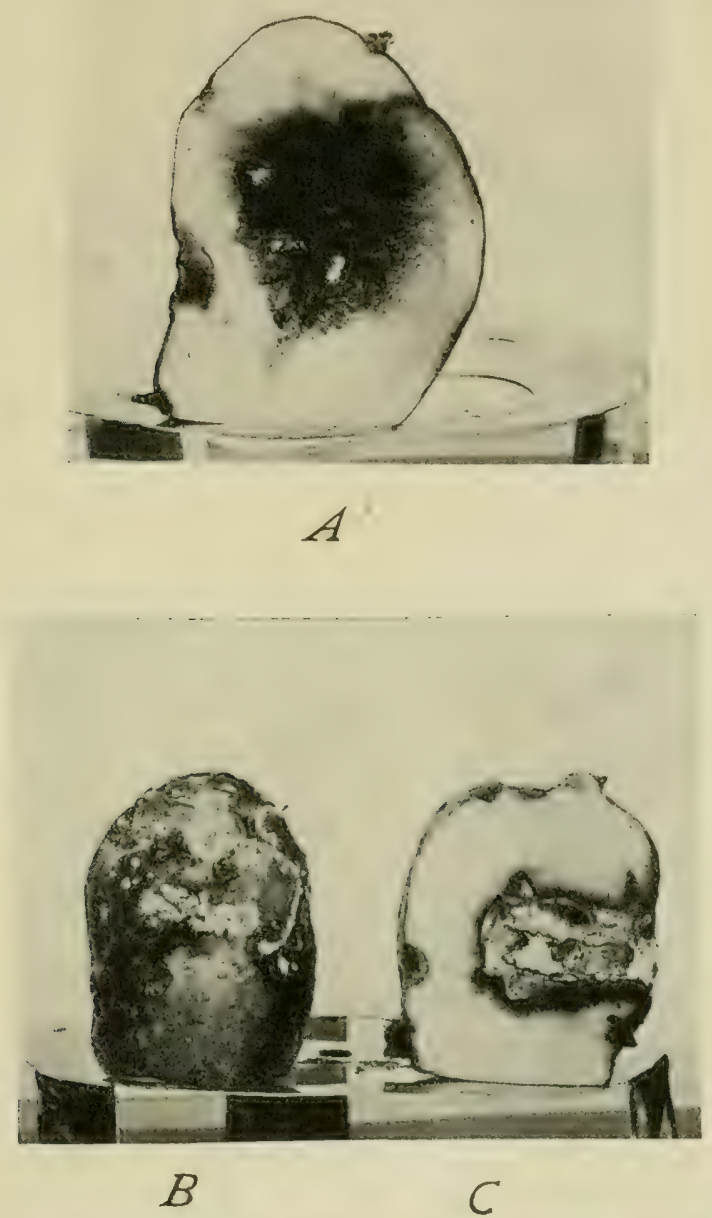

FIG. I.-Tuber rot produced in laboratory with Fusarium oxysporum, and $F$. trichothecioides; $A$, soft rot produced by $F$. oxysporum, incubated at $20^{\circ} \mathrm{C}$. for 17 days, Early Ohio variety; $B$, exterior of tuber rotted by $F$.trichothecioides, incubated at $20^{\circ} \mathrm{C}$. for I 7 days, Early Ohio variety; $C$, dry rot produced by $F$. trichothecioides, incubated at $20^{\circ} \mathrm{C}$. for 17 days, Early Ohio variety. 
producer in his I9I 3 paper, there is a reference in the I9I 2 paper by JAMIESON and Wollenweber (I6) to a wilt produced by $F$. trichothecioides. They referred to inoculation experiments, and report wilting in I2 days, "accompanied by a yellowing of the leaves and a discoloration of the tissue." The results of all of the writer's attempts of I9II-I9I 2 to produce wilting of potato plants with $F$. trichothecioides, excepting one, were negative. During the past winter, however, it was noticed again and again that sprouts of tubers experimentally infected with this organism were dying. Microscopic and cultural studies left no doubt that this organism was responsible for the death of the sprouts.

Encouraged by these observations, the writer carried out some preliminary experiments on potato plants. Quartz was sterilized in 6 inch flower pots in the autoclave, and 8 plants that were about Io $\mathrm{cm}$. high were transplanted into these, the stems of some being smeared with rice infected with $F$. trichothecioides, and those of others with rice infected with $F$. oxysporum. The plants so inoculated and the controls were kept under bell jars. In three days the three plants smeared with $F$. oxysporum and two smeared with $F$. trichothecioides were dead, while the third one of the latter set and the controls remained healthy. The experiment was also conducted with potato plants growing in the open bench in the greenhouse, with similar results. The soil in this case was not sterilized.

The potato plants used in the following experiments were grown from sterilized tubers of the Early Ohio and Red Cobbler varieties in soil in 6 inch pots which had been thoroughly sterilized by heating in an autoclave for 4 hours on two consecutive days at I $5 \mathrm{lb}$. pressure. The soil was watered with sterile water throughout the experiments.

On February I5, fifteen pots were planted with Early Ohio tubers and the soil of one set of 5 was infected with rice infected with $F$. oxysporum, of another with rice infected with $F$. Irichothecioides, while the third set was left as a control. The controls came up in due time, while not a single one of the others came up. This experiment was repeated several times, but in no case was so striking a result obtained, although it often happened that some sprouts showed lesions, that some failed to come up, and that some were 
tardy in coming up. Fusarium spp. were isolated from such lesions. These lesions are identical in appearance with lesions found on potato stems and roots in the field which often are designated as "foot disease" and ascribed to the activity of Rhisoctonia. Late in May other series were started and the soil was infected with rice and spore suspensions. No infections resulted at all, even though the inoculum was derived from the same source as that used in earlier experiments.

On March I2, sprouts that were just breaking through the ground were uncovered and smeared with rice infected either with $F$. oxysporum or with $F$. trichothecioides, 6 sprouts being used in each set. The plants were wounded no more than was inevitable in removing the soil. The soil was then replaced. The soil in the controls was removed in the same way, but no inoculum was applied. The I2 sprouts to which inoculum had been applied were killed, while the controls remained healthy. There was no spreading of the disease to other sprouts, even where an abundance of inoculum was applied.

The affected sprouts reminded one forcibly of affected sprouts in potato fields in the spring. Here and there in the fields one finds sprouts that look sickly and small, which usually wilt and die or remain sickly and small. Upon examination of such sprouts, prominent brownish, watery lesions are found. At times such sprouts overcome the trouble and make a fair growth, at least until transpiration becomes excessive. These lesions also account for many of the "poor stands" or failures of potatoes to come up evenly. If one digs in where a sprout ought to have come up, one can often find a tuber that has sprouted, but whose sprouts have been cut off entirely by such lesions. Often lateral buds develop into branches on such decapitated sprouts, only to be cut off again. If such a tuber finally manages to get a shoot above the ground, the shoot is sickly and backward. In I9I2, I9I3, and I9I4 the writer plated the inner tissue of many such sprouts and almost invariably obtained cultures of various Fusarium spp., although often associated with Rhizoctonia and bacteria. Infection experiments conducted with Rhizoctonia in I9I2-I9I3 gave almost uniformly negative results. The writer was at first inclined to refer 
the major part of the potato troubles to the activity of this organism. Even though it is not the sole or even the main cause of Nebraska potato troubles it may play an important rôle. The work of Appel (2), Corsault (8), Drayton (9), and Morse and Schapovalov (26) gave results similar to those obtained by RoLfs $(31,32)$.

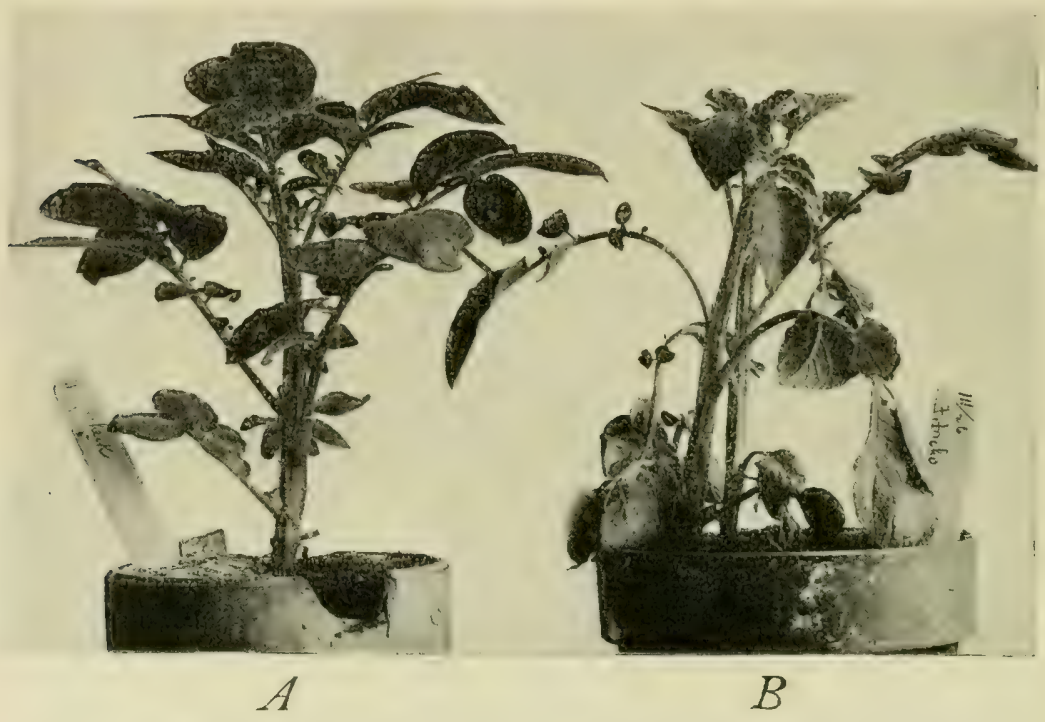

FIG. 2.-Wilt produced in laboratory with Fusarium trichothecioides, and control plant; $A$, control, Early Ohio variety; $B$, wilting and drying of leaves, 4 days after inoculation, Early Ohio variety.

On March I3, 24 plants grown in sterile soil were used in another experiment. These plants were about Io $\mathrm{cm}$. high at the time. The soil was removed from one shoot in each pot and the pots were arranged in 6 series. In series $A$ the shoots were wounded and the wound smeared with $F$. oxysporum infected rice; in series $B$ the sound stem was smeared with $F$. oxysporum infected rice; in series $C$ the wounded shoots were smeared with $F$. trichothecioides infected rice; in series $D$ the sound stems were smeared with $F$. trichothecioides infected rice; in series $E$ no inoculum was applied to the wounded shoots; in series $F$ the soil was merely removed and replaced (figs. 2 and 3 ). 
On March I 5 the following notes were taken. Series $A$ : plant I, slight curling of leaves; 2 , apparently sound; 3 , curling of leaves; 4, curling of leaves. Series B: plant I, drooping leaves; 2, lower leaves drooping, upper leaves drying; 3 , apparently sound; 4, apparently sound. Series $C$ : plant I, apparently sound; 2, some wilting; 3, some wilting; 4, some wilting. Series $D$ : plants I, 2, and 3 apparently sound; 4, wilting. By March 2r the plants

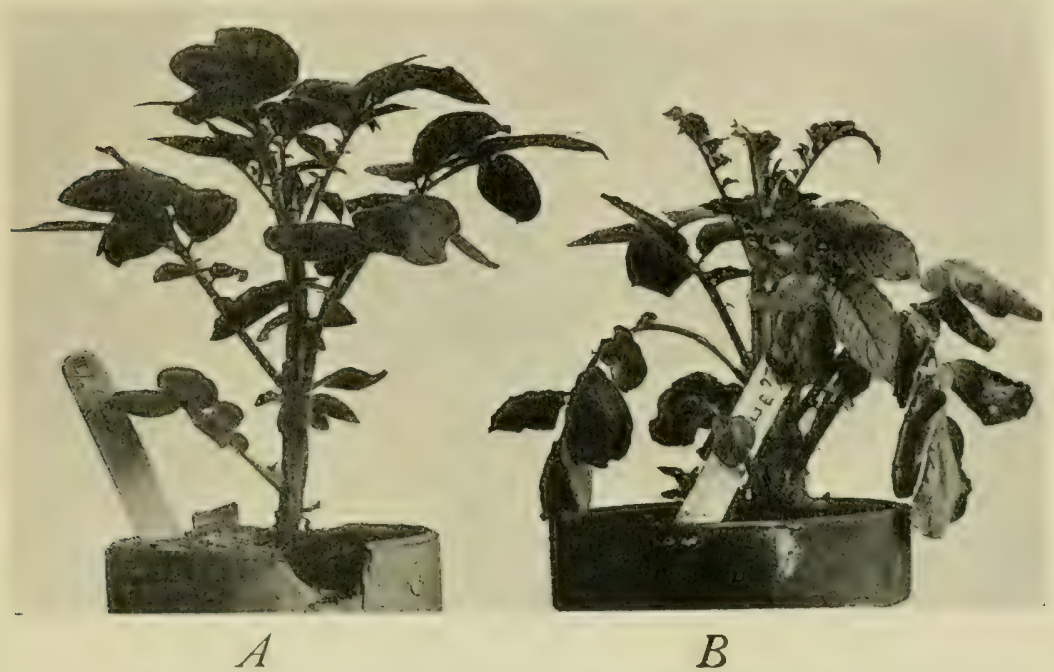

FIG. 3.-Wilt produced in laboratory with Fusarium oxysporum, and control plant; $A$, control, Early Ohio variety; $B$, wilting of lower leaves and curling of upper leaves, 4 days after inoculation, Early Ohio variety.

infected with $F$. oxysporum showed a pronounced folding upward of leaves on the midrib, wilting and rolling on the margins of the leaves, the folding being most pronounced in the tips of the plants. The plants affected least showed discoloration on the margins, which at times was of a yellowish tint, at times purplish to violet. The leaves of plants most severely affected showed a yellowing and burning of the leaf margins. One plant, inoculated with $F$. oxysponum, developed a pronounced rosette, but overcame this later, growing into quite a normal plant (figs. 4 and 5). These symptoms remind one forcibly of certain symptoms of the leaf-roll disease which has received so much attention, and which has been made the subject 
of thorough study by APPEL and his co-workers $(2,4)$. Eventually the plants infected with $F$. trichothecioides showed much severer symptoms than those inoculated with $F$. oxy'sporum (fig. 6). Eight plants died in the former sets, and 3 in the latter. Plants infected with $F$. trichothecioides showed such severe and rapid burning and

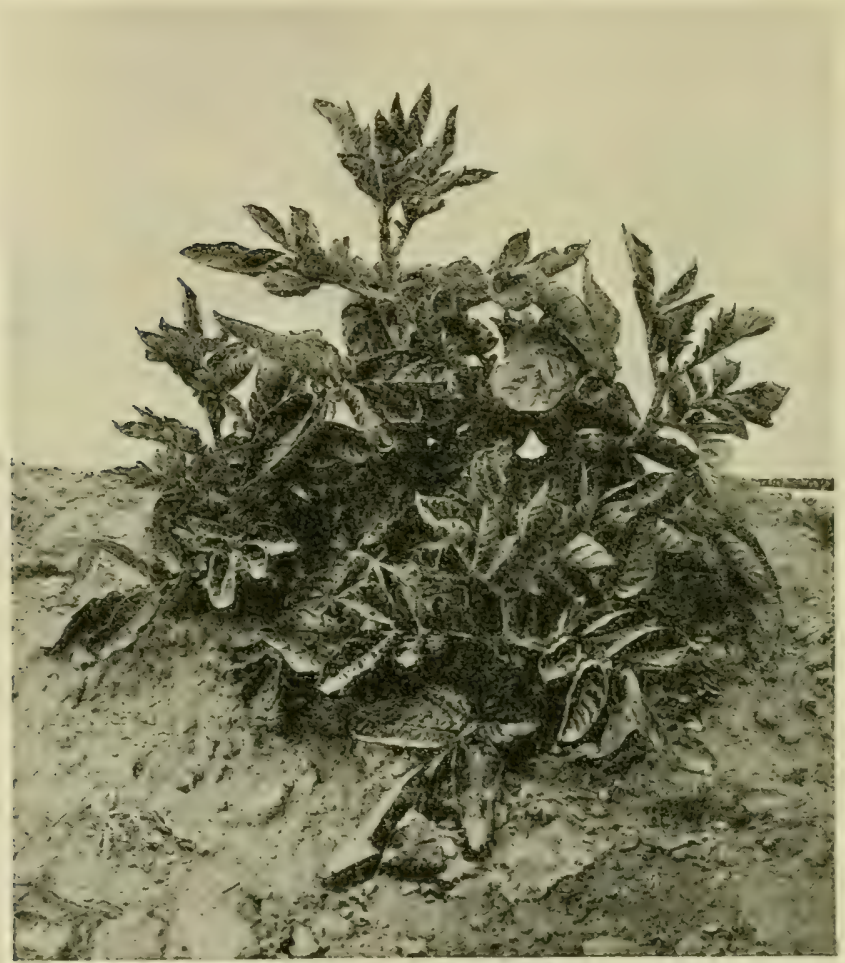

FIG. 4- Leaf roll and rosette of field plant of the Pearl variety; August igr2, at the U.S. Substation at Mitchell, Neb.

drying up of leaves, that the typical wilting phenomena were scarcely realized. The vascular bundles were blackened and the blackening extended even into the petiole and the leaf veins. This rapid killing was at first strictly localized on that side of the plant to which the inoculum had been applied, even in the leaf, where the leaflets on one side of the midrib would be affected, and those on the other side not. Eventually in those cases in which killing of the 
whole plant took place, the fungus girdled the whole stem, while plants that were not girdled lived on, even though one side was entirely destroyed. There was little lateral and subsequent vertical spreading of the fungus from one vascular strand to the other. These experiments were repeated with 25 other plants and in most cases the same symptoms were observed. These symptoms have been repeatedly observed in the dry land areas of Nebraska,

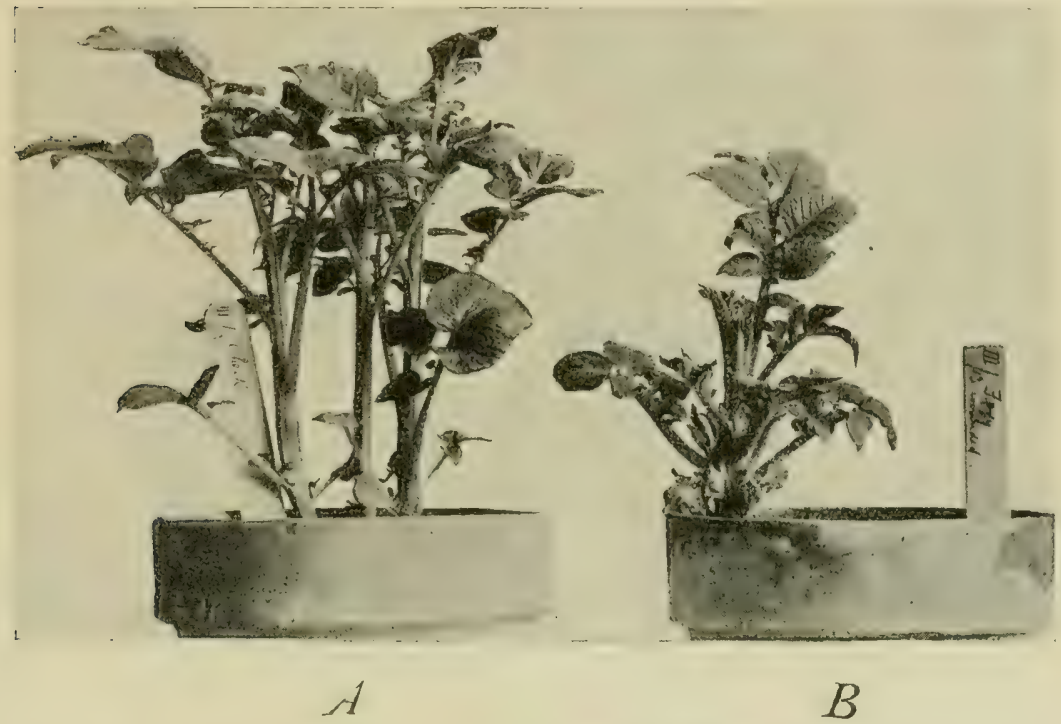

FIG. 5. - Rosette produced in laboratory with Fusarium oxysporum, and control plant; $A$, control, Early Ohio variety; $B$, rosetted plant, ro days after inoculation, Early Ohio variety.

but have always been looked upon as cases of "sun scald," and and in previous experiments with wilting due to $F$. trichothecioides such cases were ignored.

Plants grown in soil infected with $F$. oxysporum and $F$. trichothecioides showed severe lesions of root and stolons. Examination of roots affected with either organism showed that the cortical regions are first and most severely attacked, not only intercellularly, but also intracellularly, the cells being packed full with hyphae. In most cases the cortex could be sloughed off with exceeding ease. From the cortex the organisms invaded the stelar regions, where 
F. oxysporum makes greater headway than the other and there causes a vascular mycosis more frequently, which accounts for its designation as a vascular parasite (figs. 7 and 8).

Discussion.-If plants, experimentally inoculated, showed only light symptoms to begin with, most of them continued their growth with symptoms less severe than those shown in the field. If they showed severe symptoms early, these proved more severe and

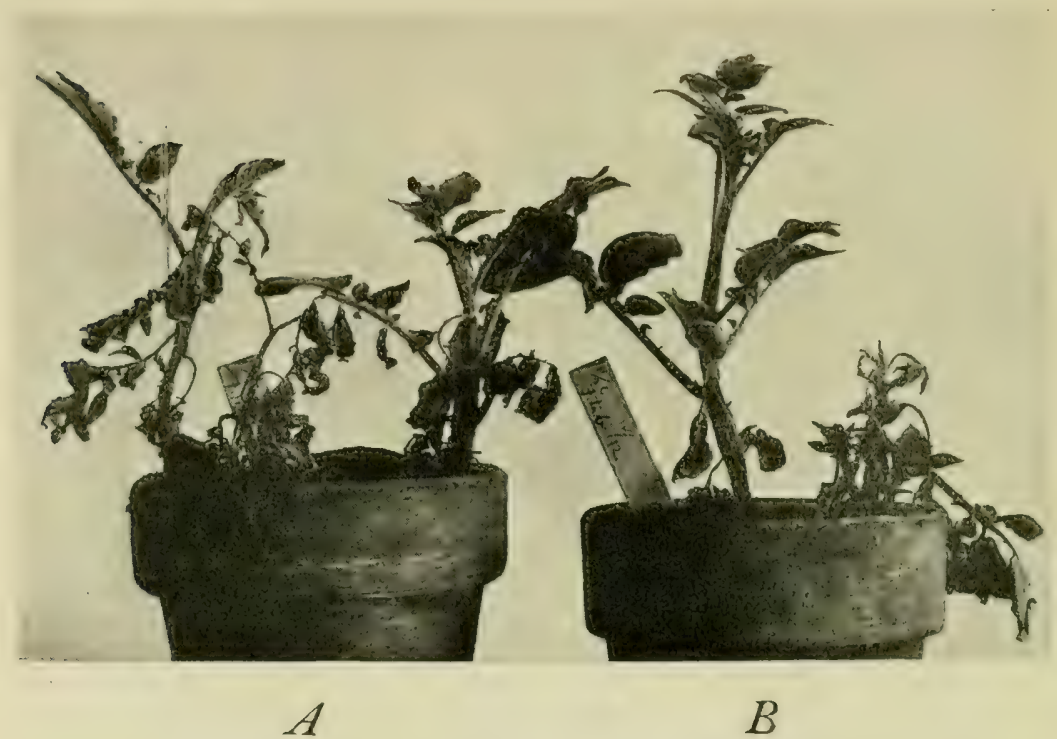

FIG. 6.-Wilt and death of potato plants produced in laboratory with Fusarium trichothecioides, I2 days after inoculation; Early Ohio variety; wilting is restricted to the side to which inoculum was applied.

more rapidly fatal than those in the field. The organisms in the field work much more insidiously, attacking the roots of the plant slowly but progressively, and permitting the plant, except in extreme cases, to readjust for its water requirements. These readjustments manifest themselves in the curling and rolling phenomena (figs. 4 and 9).

Potato plants in the irrigated sections show this phenomenon nicely. As long as cultivation and irrigation are maintained, the plant develops new roots progressively higher up, and the infected 
plants get along fairly well, showing slight curling and wilting, although tuber development occurs. When in midsummer

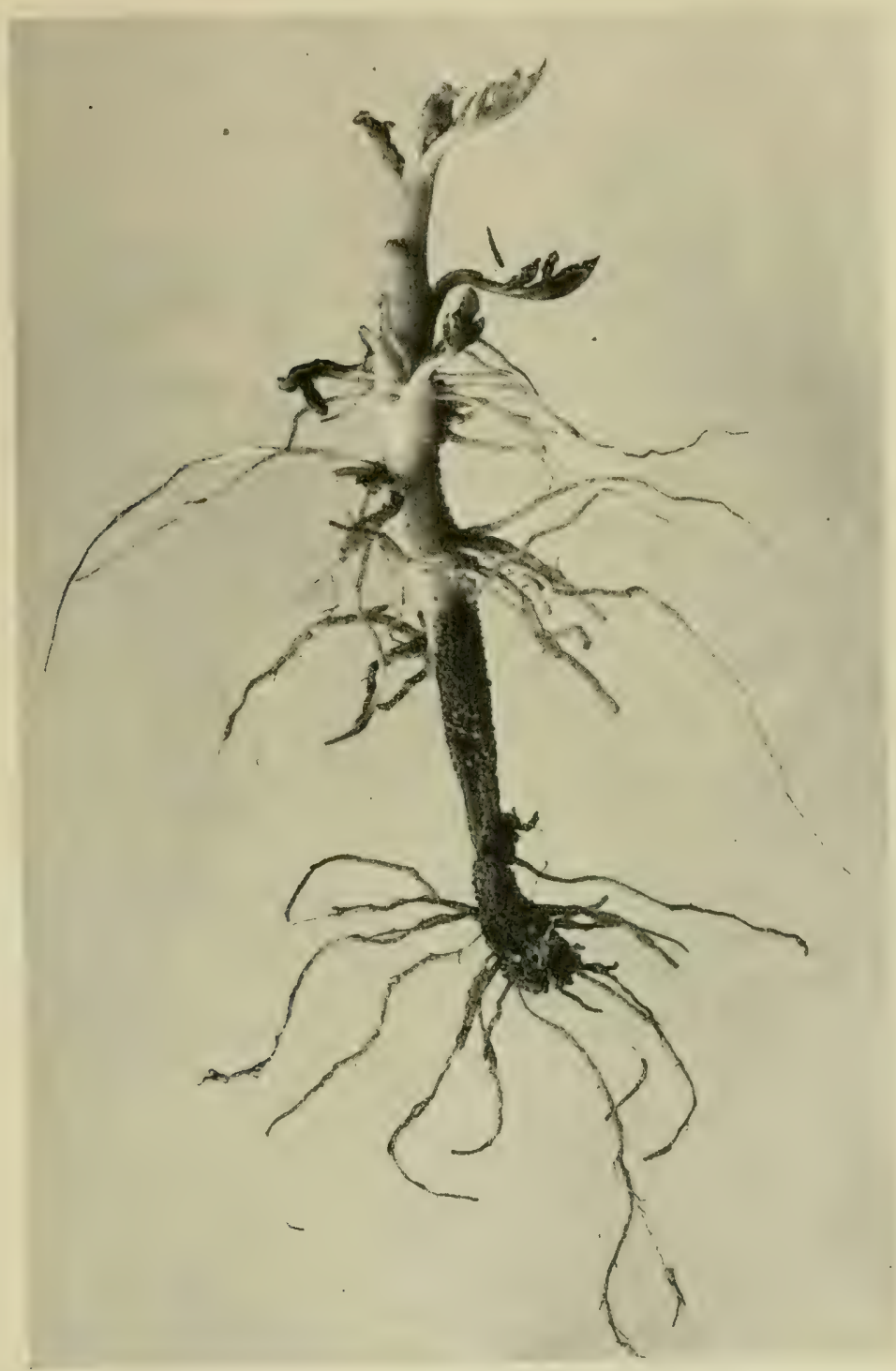

FIG. 7.-Lesions on stem and roots produced in laboratory with Fusarium oxysporum, 2 weeks after inoculation; Early Ohio variety. 


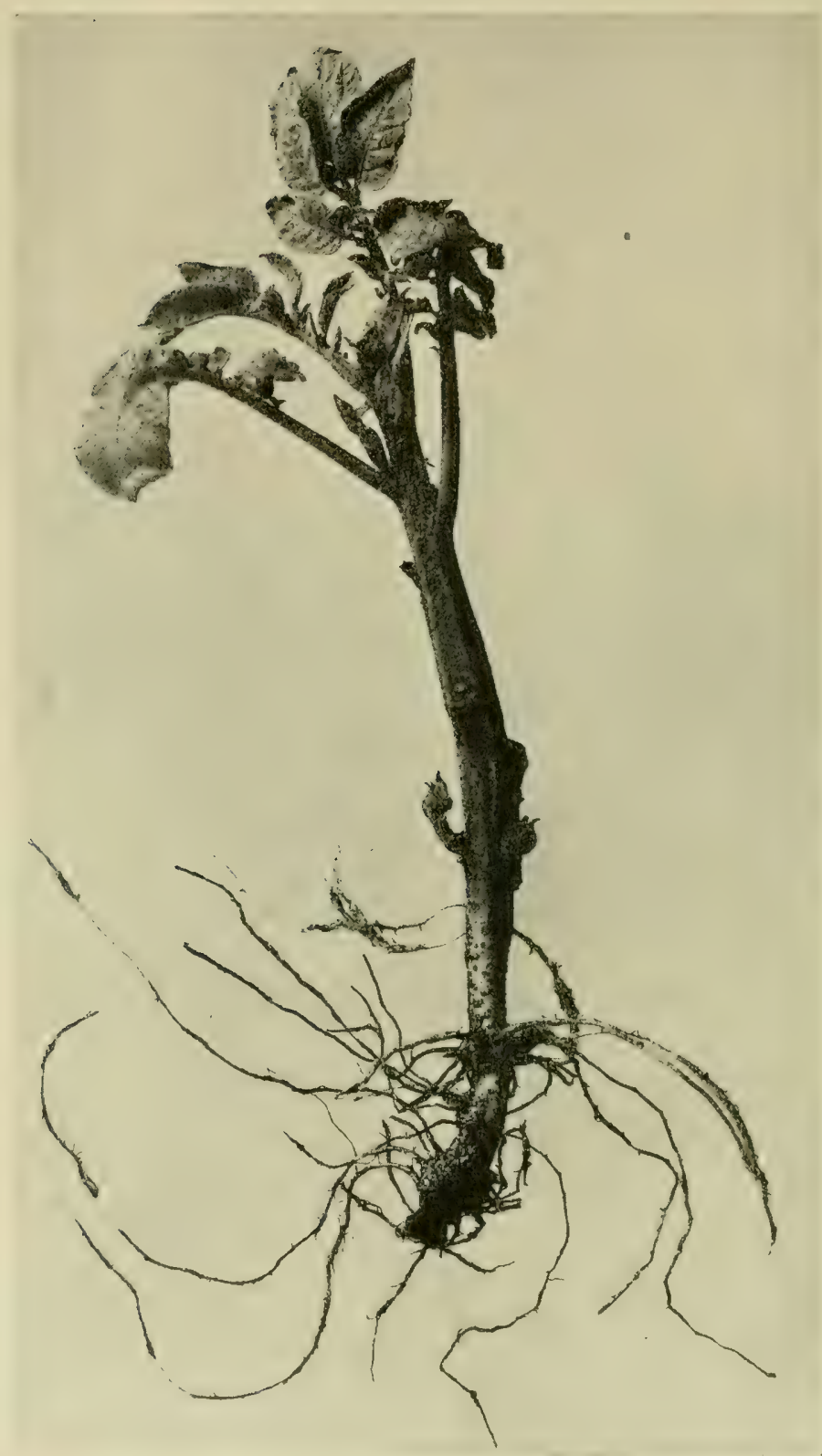

FIG. 8.-Root lesions produced in laboratory with Fusarium trichothecioides, curling and rolling of leaves, 2 weeks after inoculation; Early Ohio variety. 
irrigation ceases and no more soil is heaped about the crown of the plant and transpiration requirements must be met by badly infected

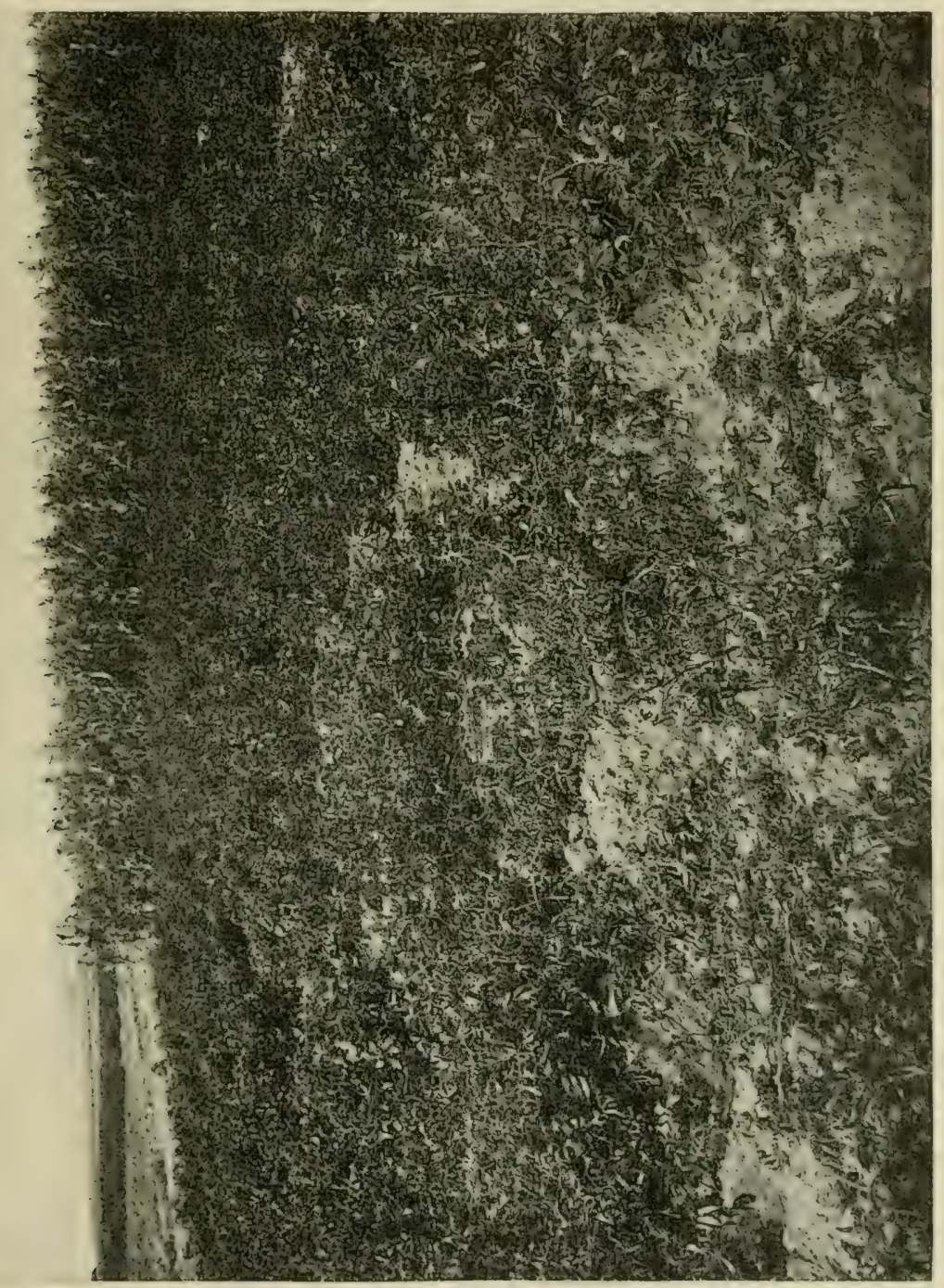

lower roots and a few healthy upper ones without the possibility of developing new roots, the plant soon succumbs. In this way we get the exceedingly frequent phenomenon of large plants, usually 
with many small tubers, wilting down suddenly after the last irrigation. The frequent occurrence of aerial tubers, the prevalence of excessive numbers of small tubers, and the occurrence of few abnormally large tubers on such plants is also attributable to the insidious manner of attack. The organisms attack the stolons and main stem as well as the roots. Stolons with tubers in all stages of maturity can be found partially or completely cut off by lesions. As the balance between the photosynthetic and storage centers in such plants is disturbed, new stolons are developed nearer and nearer the surface and the stolons that are not attacked develop abnormally large tubers. Often the plant responds to this disturbance in the assimilation-storage balance by producing swellings of the aerial parts of the plant; the so-called aerial tubers. Many large plants can be pulled up with ease, because lesions make separation of the tops from the roots or even the basal portion of the stem easy. Such plants may show a comparatively sound main axis (fig. IO).

Infection carried over by the mother tuber, which is frequent, rarely permits the growth of stems more than $20 \mathrm{~cm}$. high, and seldom allows the development of tubers. An early attack from without upon the main stem leads to equally disastrous results.

The wilts of the potato plant induced by Fusarium spp. have generally been considered vascular mycoses due to a clogging of the vascular elements. In fact, however, the symptoms are due to killing of the root system as much as to clogging of the vascular elements. It is true that members of the ELEGANS section, such as $F$. oxysporum, frequent the vascular elements, spreading in these rather than clogging them, but it is true also that they destroy roots in numbers. Again, even though some have referred to this disease as a root disease (Sмiтh and Swivgle 35), it is stated that the fungus enters a root, then spreads to the stelar part, and from there enters other roots and stolons. Just as much damage is done by the persistent attack from without upon roots and stolons, as noted by ManNs (24).

In the course of these experiments several questions were raised. The soil in these experiments surely was more severely infected with the organisms than soil under field conditions can 


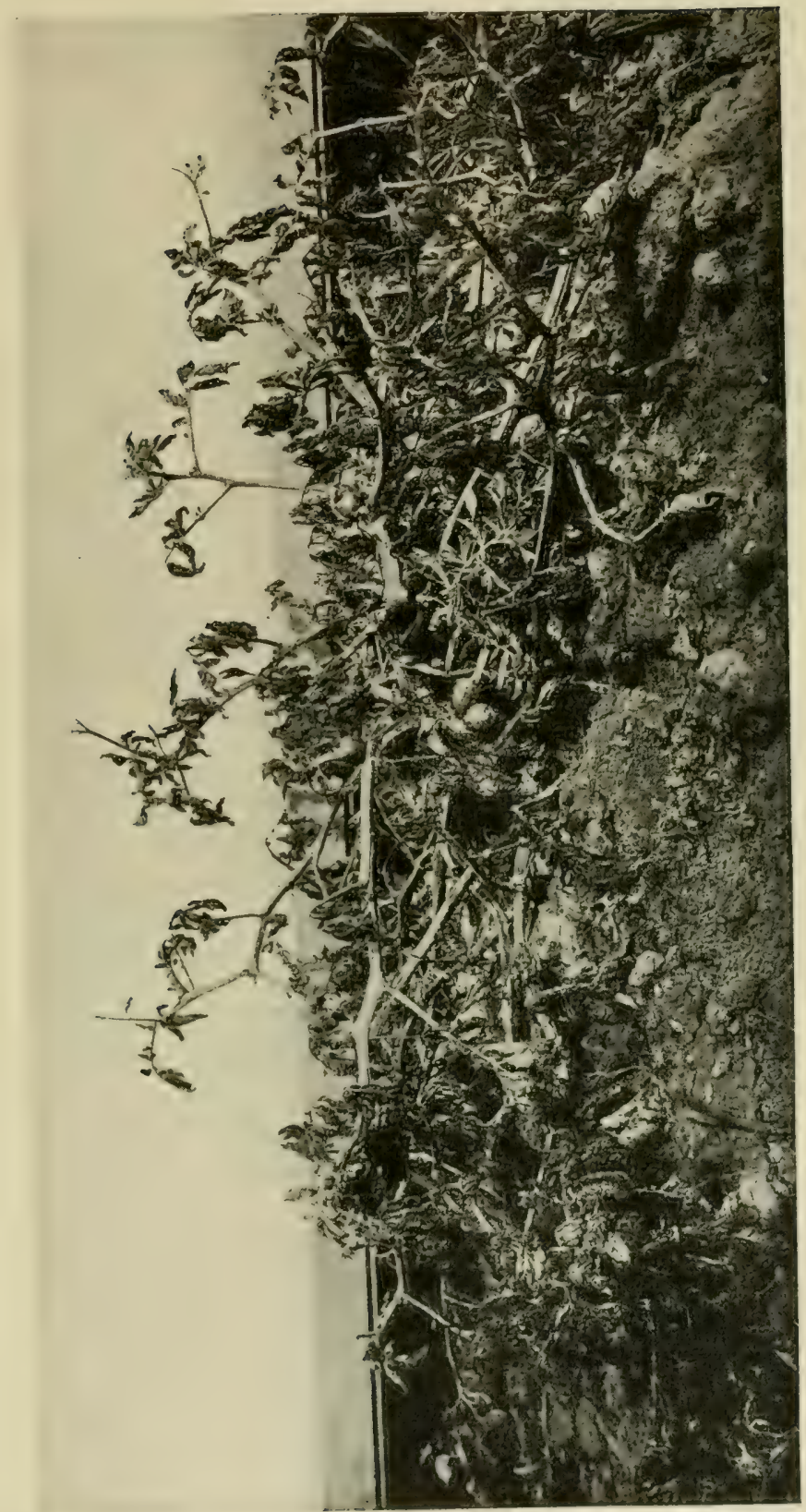

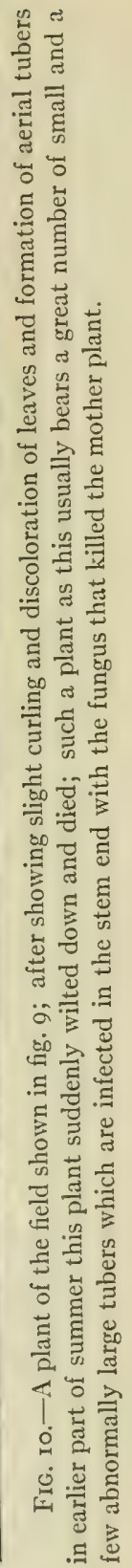


be, yet there were many plants grown in such soil that showed no infection whatsoever. Less success in producing wilt was observed as the season progressed. It remains a question whether this is due to a loss in vitality or to a gain in resistance in the plants, due to a change in the soil, tubers, or the organism.

Whether the success in producing wilt with $F$. trichothecioides and the apparent waning of this power is due to a gain or regain of virulency and a subsequent loss again is also an unanswered question. SHERBAKOFF (33), working with Fusarium spp., got uniformly negative results so far as producing wilt is concerned, and concluded that the results were due to a loss of virulency of the cultures or to some other important factor that had escaped attention.

\section{Summary}

It is quite apparent that some of the strains of $F$. oxysporum can cause tuber rot; that they can destroy tubers entirely without the aid of other Fusarium spp. or bacteria; that at least one Fusarium of the Discolor section ( $F$. trichothecioides) can produce wilt of stem; and that the biological contrast drawn by WOLLENWEBER between the Fusarium spp. is not as sharp as one would infer from his paper. It is possible that these strains of Fusarium spp. are morphologically identical with those described by WoLleNWEBER, but physiologically unlike them. That this rule, if it exists, is not so rigid generally, however, is noted by SHERbakofF (33), who found that no correlation exists between morphological relationship and pathogenicity.

Although $F$. oxysporum is not absolutely unable to attack potato parenchyma, the potato tuber, in which usually only the xylem elements are invaded, enjoys an effective immunity from its attacks; and although $F$. trichothecioides can attack any subterranean part of the living potato plant, generally all parts excepting the mature tuber enjoy an effective immunity from its attacks.

The data given in the second part of this paper may furnish a partial explanation of these phenomena. 


\section{Ecology and physiology of the organisms}

\section{METHOD AND DATA}

I. Temperature Relations.-Observations of cultures grown at ordinary temperatures showed that there is a striking difference in the rate of growth of the two organisms. Potato cylinder, rice, liquid potato, and glucose media, and glucose and potato agar cultures all showed that $F$. oxysporum makes a considerably greater initial growth at temperatures above $20^{\circ} \mathrm{C}$. than does $F$. trichothecioides. At temperatures in the vicinity of $10-15^{\circ} \mathrm{C}$., however, $F$. trichothecioides makes the greater initial growth, although these temperatures lie below its optimum. The same difference was noted in cultures on neutral and acid potato agar. This point was also tested with cultures on sterile slabs of potato tubers kept in Petri dishes. At $25^{\circ}$ C. F. oxysporum covered such slabs completely when $F$. trichothecioides barely had made a start, while at $\mathrm{I} 2{ }^{\circ} \mathrm{C}$. the situation was reversed.

When I per cent liquid glucose media were inoculated with spore suspensions of $F$. oxysporum, visible growth was made in I6 hours; when $F$. trichothecioides was used, 30-42 hours elapsed before visible growth was made. This holds for temperatures above $20^{\circ} \mathrm{C}$. The optimum temperature for $F$. oxysporum was about $30^{\circ} \mathrm{C}$., and for $F$. trichothecioides about $20-22^{\circ} \mathrm{C}$, both varying slightly with the medium used. The maximum for F. oxysporum lay between 38 and $40^{\circ} \mathrm{C}$. The optima and maxima were higher for cultures in potato extract than for glucose media cultures. The writer has not been able to determine the minima accurately because of inadequate apparatus. Humphrey (I5) gives $4^{\circ} \mathrm{C}$. as the minimum growth temperature for a certain strain of $F$. oxysporum.

Potato agar cultures of $F$. oxysporum and $F$. trichothecioides could endure a temperature of $40^{\circ} \mathrm{C}$. for 5 and for 20 hours respectively and remain viable. Exposure at $50^{\circ} \mathrm{C}$. for 5 hours killed $F$. trichothecioides, but not $F$. oxysporum; while exposure for 20 hours killed both. Some $F$. oxysporum cultures survived 5 hours exposure at $57^{\circ} \mathrm{C}$.

The growth relations were also checked up quantitatively. In these experiments, as well as in all the following ones, the method 
suggested by Hasselbring (14) was followed. Erlenmeyer flasks of $200 \mathrm{cc}$. capacity were used with $50 \mathrm{cc}$. of solution per flask. The solutions in the flasks were autoclaved for Io minutes at $7 \mathrm{lb}$. pressure, and then inoculated by means of sterile pipettes with a drop or two of spore suspension. The cultures were killed by adding Io cc. of Io per cent $\mathrm{HCl}$ to each flask. The cultures were then filtered off on tared Gooch crucibles prepared with asbestos, washed until acid free, and brought to constant weight in a Freas electric oven at $100^{\circ} \mathrm{C}$, and the dry weight determined. It was found impossible at times to filter luxuriant cultures of $F$. oxysporum by this method, because of the tenacity with which this organism holds water. Consequently they were filtered on soft filter paper, transferred to tared Gooch crucibles, dried, and weighed. The other organism holds water with little tenacity and filters with ease.

In all of experiments given below the following stock mineral solution was used: $20 \mathrm{gm} . \mathrm{NH}_{4} \mathrm{NO}_{3}$; I0 gm. $\mathrm{KH}_{2} \mathrm{PO}_{4} ; 5 \mathrm{gm}$. $\mathrm{MgSO}_{4}$ per 1000 cc. $\mathrm{H}_{2} \mathrm{O}$. When carbohydrates were employed, TABLE I

DRY WEIGHT (IN MILLIGRAMS) AFTER 20 DAYS' GROWTH IN POTATO EXTRACT MEDIUM; ROOM TEMPERATURE

\begin{tabular}{|c|c|c|c|c|c|c|}
\hline & \multicolumn{6}{|c|}{ FUSARIUM OXYSPORUM } \\
\hline & \multicolumn{6}{|c|}{ Temperature } \\
\hline & $35^{\circ}$ & $30^{\circ}$ & $25^{\circ}$ & $12^{\circ}$ & $I \circ I^{*}$ & $-I^{\circ} \mathrm{II}^{*}$ \\
\hline $\begin{array}{r}\text { Flask } 1 \ldots \ldots \\
\text { Flask } 2 \ldots \ldots \\
\text { Flask } 3 \ldots \ldots \\
\text { Average....... }\end{array}$ & $\begin{array}{l}40 \\
47 \\
61 \\
49\end{array}$ & $\begin{array}{l}55 \\
78 \\
86 \\
73\end{array}$ & $\begin{array}{l}63 \\
68 \\
80 \\
70\end{array}$ & $\begin{array}{l}64 \\
66 \\
68 \\
66\end{array}$ & $\begin{array}{c}62 \\
\cdots \cdots \cdots \\
6_{2}\end{array}$ & $\begin{array}{c}86 \\
\cdots \cdots \\
\cdots \cdots\end{array}$ \\
\hline
\end{tabular}

\begin{tabular}{|c|c|c|c|c|c|c|}
\hline & \multicolumn{6}{|c|}{ FUSARIUM TRICHOTHECIOIDES } \\
\hline & \multicolumn{6}{|c|}{ Temperature } \\
\hline & $35^{\circ}$ & $30^{\circ}$ & $25^{\circ}$ & $12^{\circ}$ & $x: \mathrm{II}^{*}$ & $-I^{0}: I^{*}$ \\
\hline Flask $1 \ldots \ldots \ldots$ & 0 & 0 & 60 & 87 & 146 & 83 \\
\hline Flask $2 \ldots . . . \ldots$ & 0 & 0 & 64 & 100 & $\ldots \ldots \ldots$ & $\ldots \ldots \ldots$ \\
\hline Flask $3 \ldots . . . \ldots$ & 0 & 0 & 65 & 147 & $\ldots \ldots \ldots$ & $\ldots \ldots \ldots$ \\
\hline Average....... & 0 & 0 & 63 & III & 146 & 83 \\
\hline
\end{tabular}

* For 20 days (no growth), then at $25^{\circ} \mathrm{C}$. for 25 days. 
these were added at the rate of Io gm. per liter. Potato extract medium was made up by extracting $500 \mathrm{gm}$. ground potato tuber with $500 \mathrm{cc} . \mathrm{H}_{2} \mathrm{O}$, and then adding $500 \mathrm{cc}$. of the foregoing solution to the extract.

A series of cultures (table II) was run at $12^{\circ} \mathrm{C}$. and the amount of dry weight formed determined at 2 day intervals for Io days. In this series the medium was at $12^{\circ} \mathrm{C}$. at the time of inoculation.

TABLE II

DRY WEIGHT (IN MILLigraMs) IN POTATO EXTRACT MEDIUM; TEMPERATURE I $2^{\circ} \mathrm{C}$.

\begin{tabular}{|c|c|c|c|c|c|c|c|c|c|c|}
\hline & \multicolumn{5}{|c|}{ FUSARIUM OXYSPORUM } & \multicolumn{5}{|c|}{ FUSARIUM TRICHOTHECIOIDES } \\
\hline & \multicolumn{5}{|c|}{ Number of days } & \multicolumn{5}{|c|}{ Number of days } \\
\hline & 2 & 4 & 6 & 8 & 10 & 2 & 4 & 6 & 8 & 10 \\
\hline I. & 0.2 & 0.4 & $5 \cdot 2$ & $\ldots$. & $\mathrm{I}_{3} .2$ & I. 4 & 4.0 & 9.4 & $\ldots \ldots$ & 27.0 \\
\hline II. . . & 0.6 & 0.4 & 5.6 & $\ldots \ldots$ & 13.0 & I. 8 & $4 \cdot 4$ & I 2.2 & $\ldots \ldots$ & $44 \cdot 6$ \\
\hline Average. & 0.4 & 0.4 & $5 \cdot 4$ & $\ldots \ldots$ & I $3 . \mathbf{I}$ & I. 6 & $4 \cdot 2$ & 10.8 & $\ldots \ldots$ & 35.8 \\
\hline
\end{tabular}

Table III shows the growth by day intervals made for to days when levulose was used as the carbon source. The solutions were at the temperatures indicated at the time of inoculation.

TABLE III

DRY WEIGHT (IN MILLIGRAMS) FORMED BY DAY INTERVALS

\begin{tabular}{|c|c|c|c|c|c|c|c|c|c|c|}
\hline & \multicolumn{10}{|c|}{ FUSARIUM TRICHOTHECIOIDES AT $25^{\circ} \mathrm{C}$. } \\
\hline & \multicolumn{10}{|c|}{ Number of days } \\
\hline & I & 2 & 3 & 4 & 5 & 6 & 7 & 8 & 9 & IO \\
\hline I. & 0.2 & 0.6 & 4.2 & I2. 8 & 29.0 & I9. 2 & $25 \cdot 4$ & I9. 4 & 34.0 & 43.6 \\
\hline 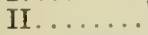 & 0.2 & 2.4 & 18.0 & 31.6 & 32.4 & 34.2 & 27.2 & 41.9 & 47.7 & 50.8 \\
\hline Average & 0.2 & I. 5 & II.I & 22.2 & 30.7 & 26.7 & 26.3 & 30.6 & 40.8 & $47 \cdot 2$ \\
\hline
\end{tabular}

\begin{tabular}{|c|c|c|c|c|c|c|c|c|c|c|}
\hline & \multicolumn{10}{|c|}{ FUSARIUM OXYSPORUM AT $25^{\circ} \mathrm{C}$. } \\
\hline & \multicolumn{10}{|c|}{ Number of days } \\
\hline & I & 2 & 3 & 4 & 5 & 6 & 7 & 8 & 9 & Io \\
\hline I. & 0.4 & $\mathbf{r . 8}$ & 9.2 & I6. 0 & 23.6 & I9. 6 & 24.0 & $24 \cdot I$ & 30.9 & 37.0 \\
\hline II ........ & 0.8 & 3.2 & 10.8 & 29.2 & 33.4 & $21 \cdot 2$ & $27 \cdot 5$ & 26.0 & 34.8 & 38.8 \\
\hline Average. & 0.6 & 2.5 & 10.0 & 22.6 & 28.5 & 20.4 & $25 \cdot 7$ & 25.0 & 32.8 & $37 \cdot 9$ \\
\hline
\end{tabular}


TABLE III-Continued

\begin{tabular}{|c|c|c|c|c|c|c|c|c|c|c|}
\hline & \multicolumn{10}{|c|}{ FUSARIUI OXYSPORUM AT $30^{\circ} \mathrm{C}$. } \\
\hline & \multicolumn{10}{|c|}{ Number of days } \\
\hline & I & 2 & 3 & 4 & 5 & 6 & 7 & s & 9 & 10 \\
\hline $\begin{array}{l}\text { II } \ldots \ldots \ldots \\
\text { Average }\end{array}$ & $\begin{array}{l}\text { 1. } 0 \\
8.9 \\
4.9\end{array}$ & $\begin{array}{l}3.6 \\
5.2 \\
4.4\end{array}$ & $\begin{array}{l}\text { I } 5.4 \\
\text { I } 7.6 \\
\text { I6.5 }\end{array}$ & $\begin{array}{l}17.8 \\
19.0 \\
18.4\end{array}$ & $\begin{array}{l}37.6 \\
40.2 \\
38.9\end{array}$ & $\begin{array}{l}45.8 \\
77.8 \\
61.8\end{array}$ & $\begin{array}{l}55.8 \\
62.6 \\
59.2\end{array}$ & $\begin{array}{l}66.0 \\
69.6 \\
67.8\end{array}$ & $\begin{array}{l}78.2 \\
78.6 \\
78.4\end{array}$ & $\begin{array}{l}62.2 \\
66.6 \\
64.4\end{array}$ \\
\hline
\end{tabular}

\begin{tabular}{|c|c|c|c|c|c|c|c|c|c|c|}
\hline & \multicolumn{10}{|c|}{ FUSARIUM TRICHOTHECIOIDES AT $25^{\circ} \mathrm{C}$. } \\
\hline & \multicolumn{10}{|c|}{ Number of days } \\
\hline & I & 2 & 3 & 4 & 5 & 6 & 7 & 8 & 9 & 10 \\
\hline Average... & $4 \cdot 4$ & I9 & 67.4 & & & & & 262 & & \\
\hline
\end{tabular}

\begin{tabular}{|c|c|c|c|c|c|c|c|c|c|c|}
\hline & \multicolumn{10}{|c|}{ FUSARIUM OXYSPORUM AT $30^{\circ} \mathrm{C}$. } \\
\hline & \multicolumn{10}{|c|}{ Number of days } \\
\hline & I & 2 & 3 & 4 & 5 & 6 & 7 & 8 & 9 & 10 \\
\hline Average. & II. 2 & 48 & 108.6 & & & & & 240.2 & & \\
\hline
\end{tabular}

These tables show a tendency of $F$. trichothecioides to make a greater initial growth at low temperatures. At higher temperatures, however, unless above the optimum of $F$. trichothecioides, $F$. oxysporum, even though it made the greater initial growth, was soon overtaken and passed by $F$. trichothecioides. This was especially marked when dextrose and levulose were used as carbon source. This may be the result of a faster though more superficial feeding of $F$. oxysporum, which makes it unable to use materials as thoroughly as the other organism. This phenomenon is hardly a case of more rapid intoxication on the part of $F$. oxysporum.

The results obtained with artificial media were verified by infection experiments conducted with potato tubers kept at various temperatures. Tubers of the Red Cobbler variety were used. These were inoculated on April I, and examined on May 27 (table IV). See figs. II and I2. 
It should be noted here that $F$. trichothecioides when inoculated into a tuber can grow at $30^{\circ} \mathrm{C}$, , while it cannot do so in artificial media; and that $F$.oxysporum can survive a temperature of $\mathrm{I}^{\circ} \mathrm{C}$. in artificial media, but not in the tuber.

TABLE IV

CONDITION OF TUBERS AT CLOSE OF EXPERIMENT

\begin{tabular}{|c|c|c|}
\hline Temperature & Fusarium oxysporum & Fusarium trichothecioides \\
\hline $30^{\circ} \mathrm{C}$ & All completely rotted; & Slight rot in some \\
\hline & All completely rotted; & All completely rotted; some \\
\hline $\begin{aligned} &{ }^{I} 2^{\circ} \mathrm{C} \ldots \ldots \\
&{ }^{\circ} \mathrm{C} \\
&{ }^{\circ} \mathrm{C} \text {. for two }\end{aligned}$ & $\begin{array}{l}\text { All with very slight rot } \\
\text { No rot }\end{array}$ & $\begin{array}{l}\text { All completely rotted } \\
\text { All with slight rot }\end{array}$ \\
\hline $\begin{array}{l}25^{\circ} \mathrm{C} \text {. for two weeks. } \\
-\mathrm{I}^{\circ} \mathrm{C} . \ldots . . . . . . . . . \\
-\mathrm{I}^{\circ} \mid \mathrm{C} \text {. for two weeks, then }\end{array}$ & $\begin{array}{l}\text { Slight rot in one tuber } \\
\text { No rot }\end{array}$ & $\begin{array}{l}\text { All completely rotted } \\
\text { No rot }\end{array}$ \\
\hline $25^{\circ} \mathrm{C}$. for two weeks. & No rot & All completely rotted \\
\hline
\end{tabular}

Discussion.-These results may, in part at least, explain why $F$. oxysporum, even though it can attack parenchyma and rot tubers, usually is not found in rotted tubers, while $F$. trichothecioides is. The ability of the latter to make a faster initial growth at the temperatures which prevail in the soil about digging time and in well kept storage places is probably the determining factor in this phenomenon. The experiments with tubers showed that $F$. trichothecioides made a great increase in growth rate when transferred from a low to a higher temperature.

These temperature relations may also explain in part the fact that we usually find $F$. oxysporum producing wilt under field conditions, and lend support to the observations made by ORToN (27), who reports potato wilt induced by Fusarium spp. to be preeminently a warm climate disease. $F$. trichothecioides can produce wilt, but the temperature conditions in the soil are such as to favor $F$. oxysporum, the maximum temperature of the former being the optimum of the latter. Humphrex (15), working in Washington on the tomato wilt induced by $F$. oxysporum, came to the conclusion that temperature differences in various parts of the state were determining factors for the appearance and non-appearance and severity of the disease. 

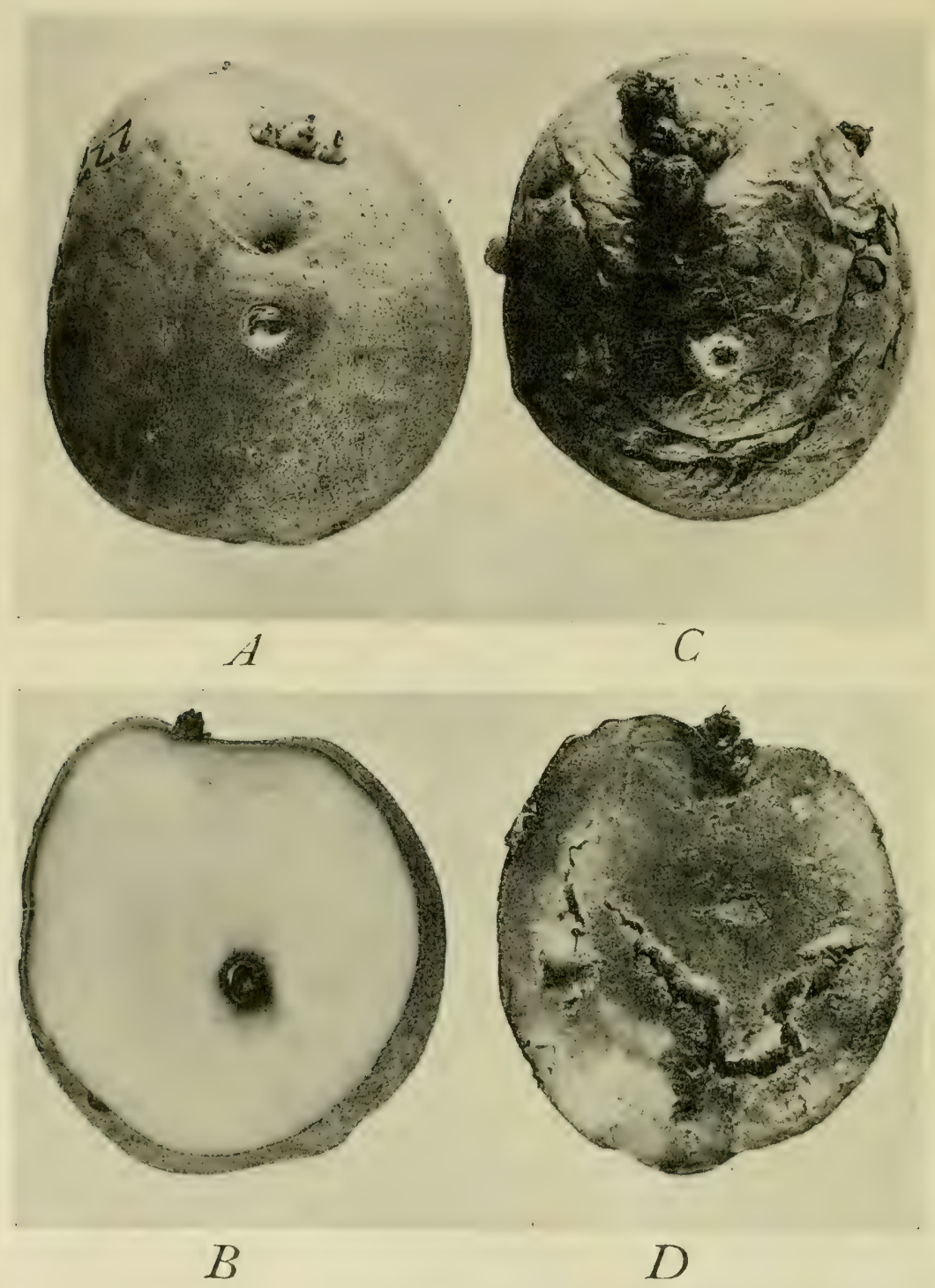

FIG. II.-Tuber rot of Red Cobbler variety produced by inoculation with Fusarium oxysporum; $A, B$, external and sectional view of same tuber, incubated for 30 days I $2{ }^{\circ} \mathrm{C}$; $C, D$, external and sectional view of same tuber, incubated for 30 days at $25^{\circ} \mathrm{C}$. 

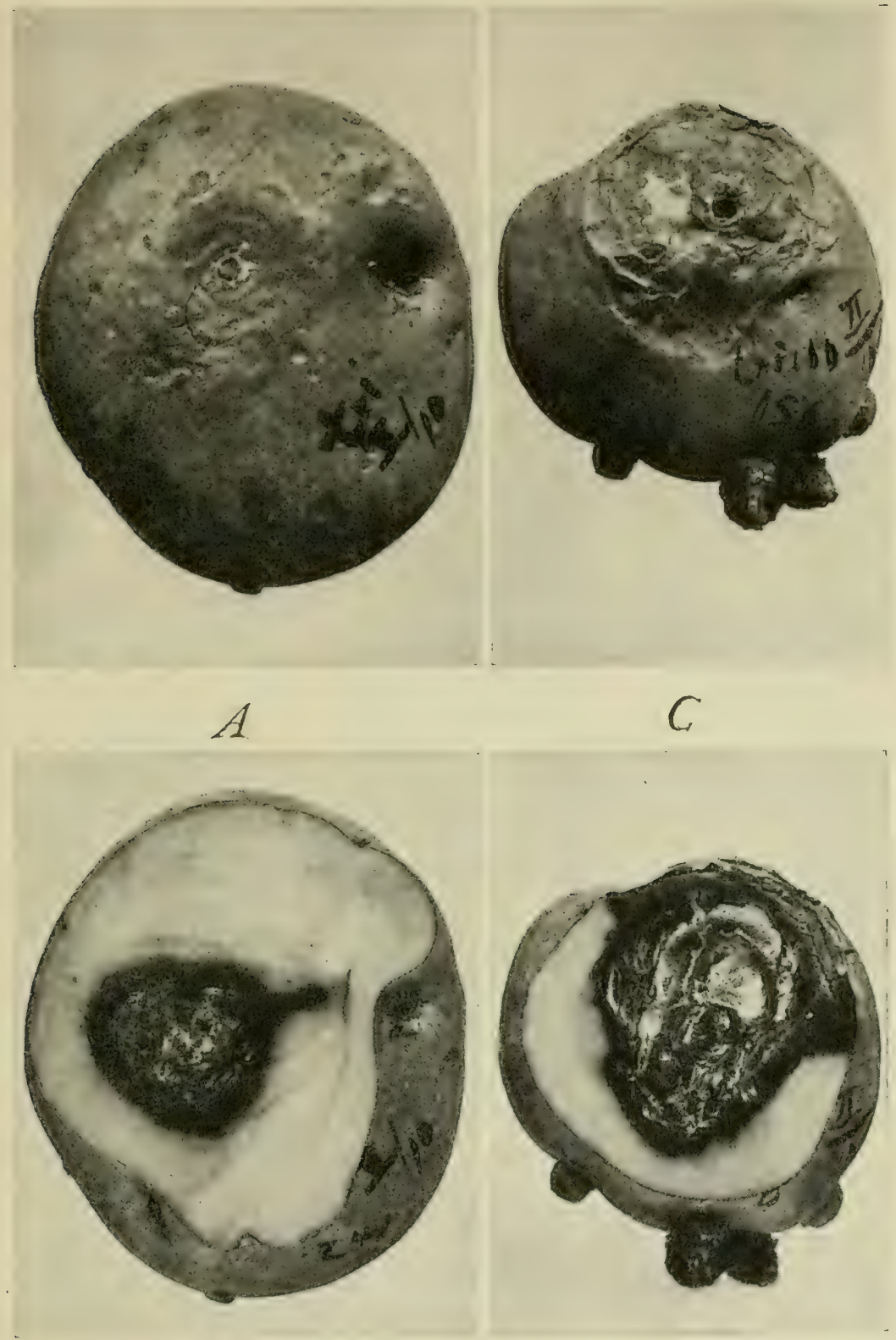

\section{$B$}

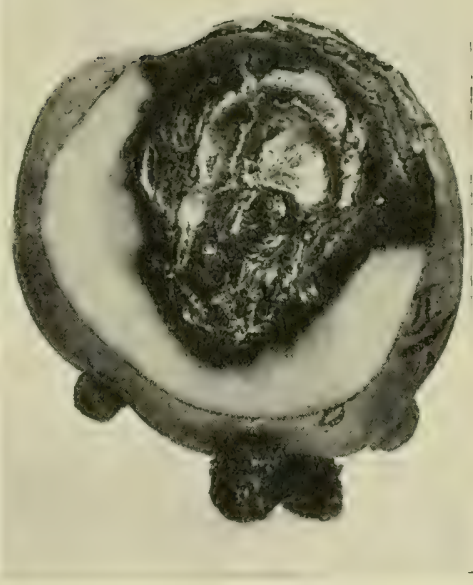

D

FIG. I2.-Tuber rot of Red Cobbler variety produced by inoculation with Fusarium trichothecioides; $A, B$, external and sectional view of same tuber, incubated for 30 days at $25^{\circ} \mathrm{C}$; $C, D$, external and sectional view of same tuber, incubated for 30 days at $12^{\circ} \mathrm{C}$. 
2. GROWtH HABIT.-It was observed in nearly all cultures that $F$. oxysporum not only made a greater initial growth at ordinary temperatures, but that it was at all temperatures much more of a surface grower than $F$. trichothecioides, making a superficial spreading growth, rather than the penetrating restricted intensive growth of the latter. Early sporulation was associated with the restricted growth habit of the latter (fig. I3). These habits were especially clearly marked on solid substrata, but even in liquid media $F$. oxyspormm made a much less compact growth than the other species. It may be that the more spreading and extensive growth habit of $F$. oxysporum at all temperatures and its more rapid initial growth at temperatures above IO-I $5^{\circ} \mathrm{C}$. are associated with a greater oxygen requirement than that possessed by $F$. trichothecioides. This would explain in part the frequenting of intercellular spaces and xylem elements by the former, and its consequent greater efficiency in causing vascular mycosis and wilt, as well as its tendency to cause bundle discoloration. The xylem elements of the stem end are undoubtedly infected while the tuber is yet in the soil, where temperature conditions are such as to favor the growth of $F$. oxysporum. Storage temperatures check the growth of this organism and the cells bordering the infected vascular elements shut the infected area off by suberizing their walls. Cultural experiments and microscopical studies show that cork is not absolutely impenetrable to these organisms, although it provides under normal conditions an effective barrier to the progress of both of these species. Because of the slower growth of $F$.trichothecioides at higher temperatures, the potato plant undoubtedly has a much better opportunity to guard itself by cork formation against this organism than against the other.

3. THE CARBON SOURCES OF THE TWO ORGANISMS,-A difference in the metabolic requirements of two organisms, a difference in their ability to utilize various substances, or a difference in their ability to tolerate the presence of substances may be factors of critical importance in determining which of the two will attack a given tissue or a given plant. These factors may determine also the modes of attack of an organism upon a tissue or a plant. Thus an organism that can digest pectinaceous material and not cellulose 
would have to destroy a tissue whose walls are mainly cellulose by intercellular activity, while one that could digest cellulose might
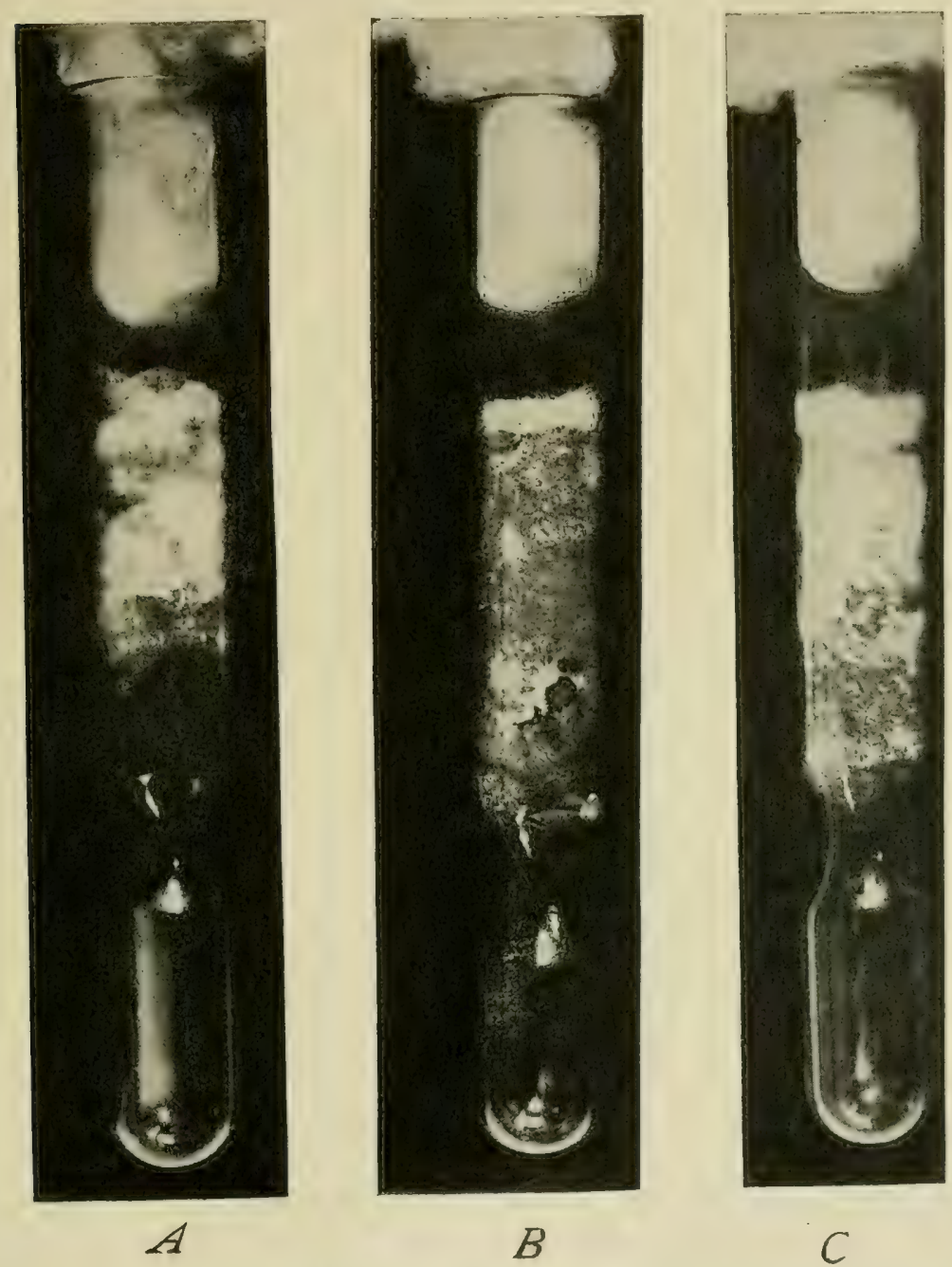

FIG. 13.-Fusarium trichothecioides and $F$. oxysporusn on sterile potato cylinders; $A, C$, cylinders inoculated with $F$. oxysporum, incubated for 2 days at $25^{\circ} \mathrm{C}$.; $B$, 'cylinder inoculated with $F$. trichothecioides, incubated for 2 days at $25^{\circ} \mathrm{C}$.

destroy this tissue by a primary cell invasion. Again, a greater ability on the part of an organism to digest suberin, other things 
being equal, would render it a much more formidable enemy of the potato plant than an organism without this ability, or possessing it to a less degree. This problem was attacked by making a study of the carbon sources of the organisms. The data reported here are only a beginning of this phase of the problem.

Fifty cc. of nutrient solution were measured quantitatively into $200 \mathrm{cc}$. Erlenmeyer flasks with a pipette. The flasks were then plugged with cotton, covered with tinfoil, and autoclaved. After cooling, $0.5 \mathrm{gm}$. of carbohydrate material was transferred quantitatively into each flask, and the flasks covered again with tinfoil and sterilized in a Freas oven by heating at $85^{\circ} \mathrm{C}$. for one hour every I 2 hours, for 6 consecutive days. The solutions were then incubated at $25^{\circ} \mathrm{C}$. for 48 hours, so as to allow any contaminations present to appear. Low sterilization temperature was used to reduce hydrolysis of carbohydrates to a minimum.

The dry weight determinations were made by the methods outlined above. It was found advisable to kill two cultures of each set after 6 days, for the striking differences in rate of growth between the two organisms that were observed during the first 48-120 hours were obliterated by prolonged growth. The other 3 cultures were killed after I2 days' growth. The dry weight values do not show the differences in habit and rate of growth in the cultures as strikingly as they appeared to the eye. In many cases a visible growth was not determinable as dry weight. This is readily appreciated when we consider that moisture determinations indicated that the dry weight varied between Io and 20 per cent of the wet weight.

In the controls, consisting of the plain mineral medium without carbon material, $F$. oxysporum made a weighable growth in $\mathrm{I} 2$ days, though not in 6 days, while $F$. trichothecioides made no weighable growth even after I2 days. Another important observation was made. In no case was it necessary to reinoculate with $F$. oxysporum, while many $F$. trichothecioides inoculations failed. The latter undoubtedly is the slower starter and much more poorly equipped for sure and quick infection than the former.

The figures in tables V-VIII represent milligrams of dry weight of material formed, except in those cases in which per cent is written. In such cases (cork, cellulose, and hemicellulose), the figures repre- 
sent the percentage of decrease in dry weight of material. The last weighing in these cases unavoidably included the dry weight of fungus material formed, so that the figures are higher than they ought to be. The differences in weight in these cases give only comparative values of the amounts of material respired by the organisms. The filter paper used was the best Swedish paper, and the cork was obtained by skinning steamed potatoes, scrubbing the skin thoroughly, boiling it for 48 hours in distilled water, extracting for 48 hours in ether, and then boiling again with water. All figures represent averages, the composition of these figures being shown in tables VI and VII. In many cases there was a fair coincidence of the values, while in others a great disparity appeared. The averages probably would more nearly approximate the true value if a greater number of figures were available.

TABLE V

DRY WEIGHT (IN MILLIGRAMS) FORMED IN 6 AND I2 DAYS BY Fusarium trichothecioides AND $F$. oxysporum

\begin{tabular}{|c|c|c|c|c|}
\hline & \multirow{2}{*}{\multicolumn{2}{|c|}{$\begin{array}{c}\text { FUSARIUM TRICHOTHECIOIDES } \\
\text { Number of days }\end{array}$}} & \multirow{2}{*}{\multicolumn{2}{|c|}{$\frac{\text { FUSARIUM OXYSPOR UM }}{\text { Number of days }}$}} \\
\hline & & & & \\
\hline & 6 & $\mathrm{I} 2$ & 6 & I 2 \\
\hline 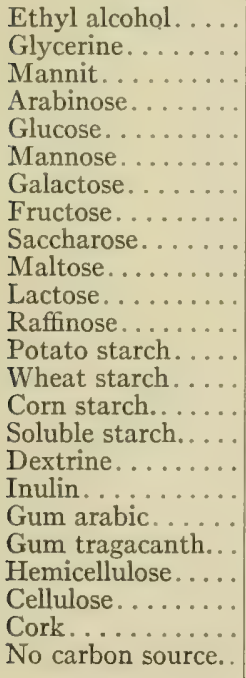 & 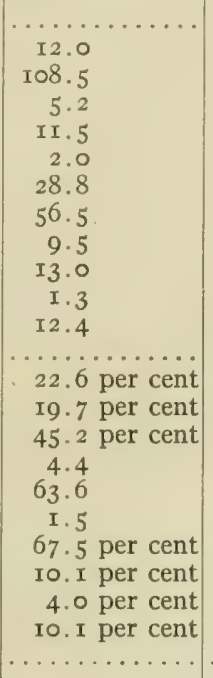 & $\begin{array}{r}\text { I. } 2 \\
20.5 \\
136.3 \\
35.0 \\
42.3 \\
52.0 \\
43.3 \\
81.0 \\
45.6 \\
61.0 \\
20.0 \\
47.3 \\
45.0 \text { per cent } \\
42 . \text { I per cent } \\
33.4 \text { per cent } \\
49.0 \text { per cent } \\
37.3 \\
\text { I23.0 } \\
\text { I8.6 } \\
\text { I4. I per cent } \\
7.3 \text { per cent } \\
\text { I.0 per cent } \\
\text { 5.9 per cent } \\
\ldots \ldots \ldots\end{array}$ & \begin{tabular}{|} 
I5.0 \\
I 7.0 \\
IO9.5 \\
78.7 \\
43.5 \\
49.0 \\
39.0 \\
74.5 \\
36.5 \\
35.5 \\
4.0 \\
44.5 \\
81.0 \\
54.3 per cent \\
37.9 per cent \\
I I0.5 \\
42.0 \\
IO2.0 \\
37.0 \\
27.1 per cent \\
I0. I per cent \\
4.25 per cent \\
I2.8 per cent \\
$\ldots \ldots \ldots$
\end{tabular} & $\begin{array}{l}\text { I8.5 } \\
92.0 \\
\text { I I } 2.0 \\
43.0 \\
44.0 \\
62.0 \\
73.0 \\
77.6 \\
35.6 \\
50.3 \\
21.0 \\
54.6 \\
\text { I03.0 } \\
\text { I27.0 } \\
67.2 \text { per cent } \\
210.3 \\
56.3 \\
90.0 \\
58.3 \\
25.7 \\
6.7 \text { per cent } \\
6.7 \text { per cent } \\
3.9 \text { per cent } \\
0.5\end{array}$ \\
\hline
\end{tabular}


Table $\mathrm{V}$ shows that qualitatively the two organisms behave alike in their ability to use all the carbon compounds tested. Quantitatively there is considerable difference, both as to rate of consumption and total growth after $\mathrm{I} 2$ days. F. oxysporum in general shows the greater speed of growth and greater growth after twelve days. In some cases $F$. trichothecioides shows the greater growth after I2 days.

\section{TABLE VI}

DRY WEIGHT (IN MILLIGRAMS) FORMED WHEN EACH FLASK RECEIVED 0.5 GM. OF MANNIT; CONCENTRATION I PER CENT

\begin{tabular}{|c|c|c|c|c|}
\hline \multirow{2}{*}{ NUMBER OF FLASK } & \multicolumn{2}{|c|}{ FUSARIUM OXYSPORUM } & \multicolumn{2}{|c|}{ FUSARIUM TRICHOTHECIOIDES } \\
\hline & 6 days & I2 days & 6 days & I2 days \\
\hline 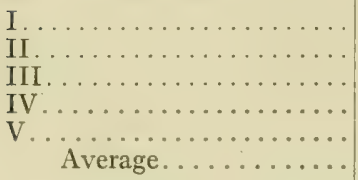 & 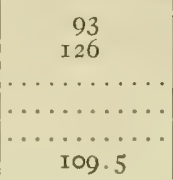 & $\begin{array}{l}\ldots \ldots \ldots \\
\quad \ldots \ldots \ldots \\
\quad \text { I } 12 \\
\quad \text { II6 } \\
\quad \text { II2 }\end{array}$ & 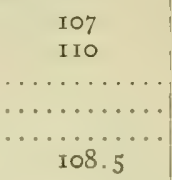 & $\begin{array}{l}\ldots \ldots \ldots \\
\ldots \ldots \ldots \\
\\
\quad \text { I30 } \\
\\
\quad \text { I } 35 \\
\\
\quad \text { I } 36.3\end{array}$ \\
\hline
\end{tabular}

TABLE VII

HeMicellulose (IN GM.) USED IN I2 DAYS

\begin{tabular}{|c|c|c|c|c|c|c|}
\hline \multirow{3}{*}{ No. OF FLASK } & \multicolumn{3}{|c|}{ FUSARIUM OXYSPORUM } & \multicolumn{3}{|c|}{ FUSARIUM TRICHOTHECIOIDES } \\
\hline & \multicolumn{3}{|c|}{6 days } & \multicolumn{3}{|c|}{6 days } \\
\hline & $\begin{array}{c}\text { Grams of } \\
\text { material }\end{array}$ & $\begin{array}{l}\text { Decrease in } \\
\text { weight }\end{array}$ & $\begin{array}{c}\text { Percentage of } \\
\text { decrease }\end{array}$ & $\begin{array}{l}\text { Grams of } \\
\text { material }\end{array}$ & $\begin{array}{c}\text { Decrease in } \\
\text { weight }\end{array}$ & $\begin{array}{l}\text { Percentage of } \\
\text { decrease }\end{array}$ \\
\hline $\begin{array}{r}\text { I. . . . . . . . . . . . . } \\
\text { Average. }\end{array}$ & $\begin{array}{c}0.5055 \\
0.5154 \\
\ldots \ldots\end{array}$ & $\begin{array}{l}0.0455 \\
0.0584 \\
\ldots \ldots\end{array}$ & $\begin{array}{r}9.0 \\
\text { II. } 3 \\
\text { IO. I }\end{array}$ & $\begin{array}{c}0.5213 \\
0.4964 \\
\ldots . . .\end{array}$ & $\begin{array}{c}0.0513 \\
0.0524 \\
\ldots \ldots \ldots\end{array}$ & $\begin{array}{r}9.8 \\
\text { IO. } 5 \\
\text { 10. I }\end{array}$ \\
\hline
\end{tabular}

\begin{tabular}{|c|c|c|c|c|c|c|}
\hline \multirow[b]{2}{*}{$\begin{array}{l}\text { III. . . . . . . . . . . } \\
\text { IV Average. }\end{array}$} & \multicolumn{3}{|c|}{ I2 days } & \multicolumn{3}{|c|}{ I2 days } \\
\hline & $\begin{array}{c}0.5185 \\
0.5192 \\
\ldots \ldots \ldots\end{array}$ & $\begin{array}{c}0.0355 \\
0.0382 \\
\ldots \ldots\end{array}$ & $\begin{array}{l}6.1 \\
7.3 \\
6.7\end{array}$ & $\begin{array}{c}0.501 \\
0.5058 \\
\ldots . . .\end{array}$ & $\begin{array}{c}0.028 \\
0.0488 \\
\ldots . . .\end{array}$ & $\begin{array}{l}5 \cdot 5 \\
9 \cdot 4 \\
7 \cdot 3\end{array}$ \\
\hline
\end{tabular}

Table VIII gives the dry weight formed by the organisms when carbon acids were furnished as carbon sources. N/roo solutions were used, excepting for asparagin and asparagenic acid, whose solu- 
bility permitted only $\mathrm{N} / 200$ solutions. In the case of the higher fatty acids and oils, the material was weighed out as though N/ Ioo solutions were being prepared. With these no weighings of the material formed were attempted, but merely differences in luxuriance of growth were recorded. To those acids which showed no growth with $\mathrm{N}$ / Ioo solutions, $5 \mathrm{cc}$. of Io per cent glucose solution was added, making the sugar concentration I per cent, so as to determine whether the acid was merely non-usable, or whether it was toxic. Since it was found that some were toxic at N/ Ioo concentration, lower concentrations were made up also. The results are given in table IX.

\section{TABLE VIII}

DRY WEIGHT (IN MILLIGRAMS) FORMED WITH THE FOLLOWING CARBON COMPOUNDS AS CARBON SOURCES

\begin{tabular}{|c|c|c|c|c|}
\hline & \multirow{2}{*}{\multicolumn{2}{|c|}{$\begin{array}{c}\text { F USARIUM TRICHOTHECIOIDES } \\
\text { Number of days }\end{array}$}} & \multicolumn{2}{|c|}{ FUSARIUM OXYSPORUM } \\
\hline & & & \multicolumn{2}{|c|}{ Number of days } \\
\hline & 6 & 12 & 6 & I 2 \\
\hline Formic acid N/roo.... & None & None & None & None \\
\hline $\begin{array}{l}+5 \text { cc. ro per cent glu- } \\
\text { cose solution }\end{array}$ & " & $"$ & $"$ & \\
\hline Acetic acid N/roo..... & “" & “ & $\mathrm{I} .2$ & $\begin{array}{l}85.5 \\
10.6\end{array}$ \\
\hline $\begin{array}{l}+5 \text { cc. ro per cent glu- } \\
\text { cose solution...... }\end{array}$ & " & 106 & None & None \\
\hline Proprionic acid N/Ioo. & “ & None & & 16 \\
\hline $\begin{array}{l}\text { +5 cc. Io per cent glu- } \\
\text { cose solution...... }\end{array}$ & “" & " & " & “ \\
\hline $\begin{array}{l}\text { Butyric acid N/I0o... } \\
+5 \text { cc. Io per cent glu- }\end{array}$ & " & " & " & “ \\
\hline cose solution...... & " & " & “ & “ \\
\hline $\begin{array}{l}\text { Glycocollic acid N/I0o. } \\
\text { Lactic acid N/I00.... }\end{array}$ & $\begin{array}{l}2.5 \\
0.3\end{array}$ & $\begin{array}{l}7.3 \\
0.6\end{array}$ & $\begin{array}{r}20.0 \\
8.0\end{array}$ & $\begin{array}{r}8.6 \\
23.0\end{array}$ \\
\hline Oxalic acid $\mathrm{N} /$ I00.... & Non-weighable & Non-weighable & Non-weighable & Non-weighable \\
\hline Succinic acid N/100. . & Non-weighable & Non-weighable & 8.5 & 9.3 \\
\hline Malic acid $N /$ Ioo.... & Non-weighable & Non-weighable & 4.5 & 8.0 \\
\hline Tartaric acid N/IOo. & I. 0 & 0.93 & 6.0 & $4 \cdot 3$ \\
\hline Citric acid N/Ioo. & 2.6 & 6.6 & 8.0 & 6.6 \\
\hline Aspartic acid $N / 200 \ldots$ & x.6 & & $5 \cdot 5$ & 6.5 \\
\hline Asparagin $\mathrm{N} / 200 \ldots \ldots$ & $3 \cdot 5$ & 3.8 & $5 \cdot 5$ & $5 \cdot 3$ \\
\hline Tannic acid I per cent. & I.0 & $3 \mathrm{I} .0$ & 0.2 & 42.0 \\
\hline $\begin{array}{l}\text { Tannic acid } 0.5 \text { per cent } \\
+5 \mathrm{cc} \text {. Io per cent glu- }\end{array}$ & r. 6 & $6 \mathbf{r . 0}$ & I.6 & $4 \mathrm{I} .0$ \\
\hline cose............. & $3 \cdot 5$ & 32.0 & 5.0 & 47.0 \\
\hline $\begin{array}{r}\text { Control } 0.5 \text { gm. levu- } \\
\text { lose.............. }\end{array}$ & & 82.0 & & II 6.0 \\
\hline
\end{tabular}




\begin{tabular}{|c|c|c|c|c|}
\hline & \multicolumn{2}{|c|}{$\begin{array}{l}\text { FUSARIUNY } \\
\text { TRICHOTHECIOIDES }\end{array}$} & \multicolumn{2}{|c|}{$\begin{array}{l}\text { F USARIUM } \\
\text { OXYSPORUM }\end{array}$} \\
\hline & \multicolumn{2}{|c|}{ I2 days } & \multicolumn{2}{|c|}{ I2 days } \\
\hline Palmitic acid I. & No & growth & Good & wth \\
\hline " $\quad$ " III. & $\underset{*}{\text { Slight }}$ & “ & $"$ & $"$ \\
\hline " $\quad$ IV. & “ & “ & “ & “ \\
\hline$+5 \mathrm{cc}$. Io per cent dextrose, $\mathrm{V}$ & Excellent & “ & “ & " \\
\hline Stearic acid, I............ & Slight & " & " & “ \\
\hline & No & $"$ & " & " \\
\hline " $\quad$ " $\quad$ II. & No « & “ & $"$ & “ \\
\hline " " IV.. & “ & “ & " & " \\
\hline+5 cc. Io per cent dextrose, $V$ & Excellent & " & " & " \\
\hline Oleic acid, $I_{\|} \ldots \ldots \ldots \ldots \ldots \ldots$ & No & " & $"$ & $"$ \\
\hline $\begin{array}{lll}\text { " } & \text { II. . . . } \\
\text { " } & \text { III..... }\end{array}$ & Poor & “ & “ & “ \\
\hline " IV.. & " & “ & “ & “ \\
\hline$+5 \mathrm{cc}$. xo per cent dextrose, $\mathrm{V}$ & Slight & “ & “ & “ \\
\hline Palm oil, I. I & No & " & $\mathrm{No}_{\text {“ }}$ & “ \\
\hline " " III..... & “ & “ & “ & " \\
\hline "IV .... & “ & “ & “ & “ \\
\hline+5 cc. Io per cent dextrose, $V$. & " & " & “ & " \\
\hline Olive oil, I. ${ }_{\text {II }} \ldots \ldots \ldots \ldots \ldots$ & Fair & “ & Fair & “ \\
\hline " " III. & “ & “ & “" & " \\
\hline " $\quad$ IV $\ldots \ldots \ldots \ldots \ldots \ldots$ & " & " & “ & " \\
\hline
\end{tabular}

A marked difference was found in the ability of the two organisms to use the fatty acids, $F$. trichothecioides being much more restricted in its ability. The experiments with alcohol and the acids also showed that the former organism was much more readily poisoned and inhibited in its growth. It was found that $F$. oxysporum grew well in I per cent ethyl alcohol, and that $F$. trichothecioides made no growth. The solution was then diluted one-half, whereupon $F$. trichothecioides made a good growth. This was clearly a case of inhibition. The growth of $F$. trichothecioides was inhibited by $\mathrm{N} /$ I00 acetic acid, as can be seen by the fact that it grew in N/ 25 concentration and that it grew in N/I00 when glucose was added, while $F$. oxysporum grew well in $\mathrm{N} /$ Ioo acetic acid. $\mathrm{N} /$ Ioo formic acid was toxic to $F$. trichothecioides, while it merely inhibited growth with the other organism. The latter grew in $\mathrm{N} / \mathrm{r} 25$ formic acid, while $F$. trichothecioides did not grow in N/500 
solution. N/IOo proprionic acid was toxic to both, while both grew in $\mathrm{N} / 250$ solution. $\mathrm{N} / 250$ butyric acid was toxic to $F$. trichothecioides, while $F$. oxysporum grew in it.

\section{TABLE IX}

DRY WEIGHT (IN MILLIGRAMS) FORMED IN I2 DAYS IN VARIOUS CONCENTRATIONS OF ACID

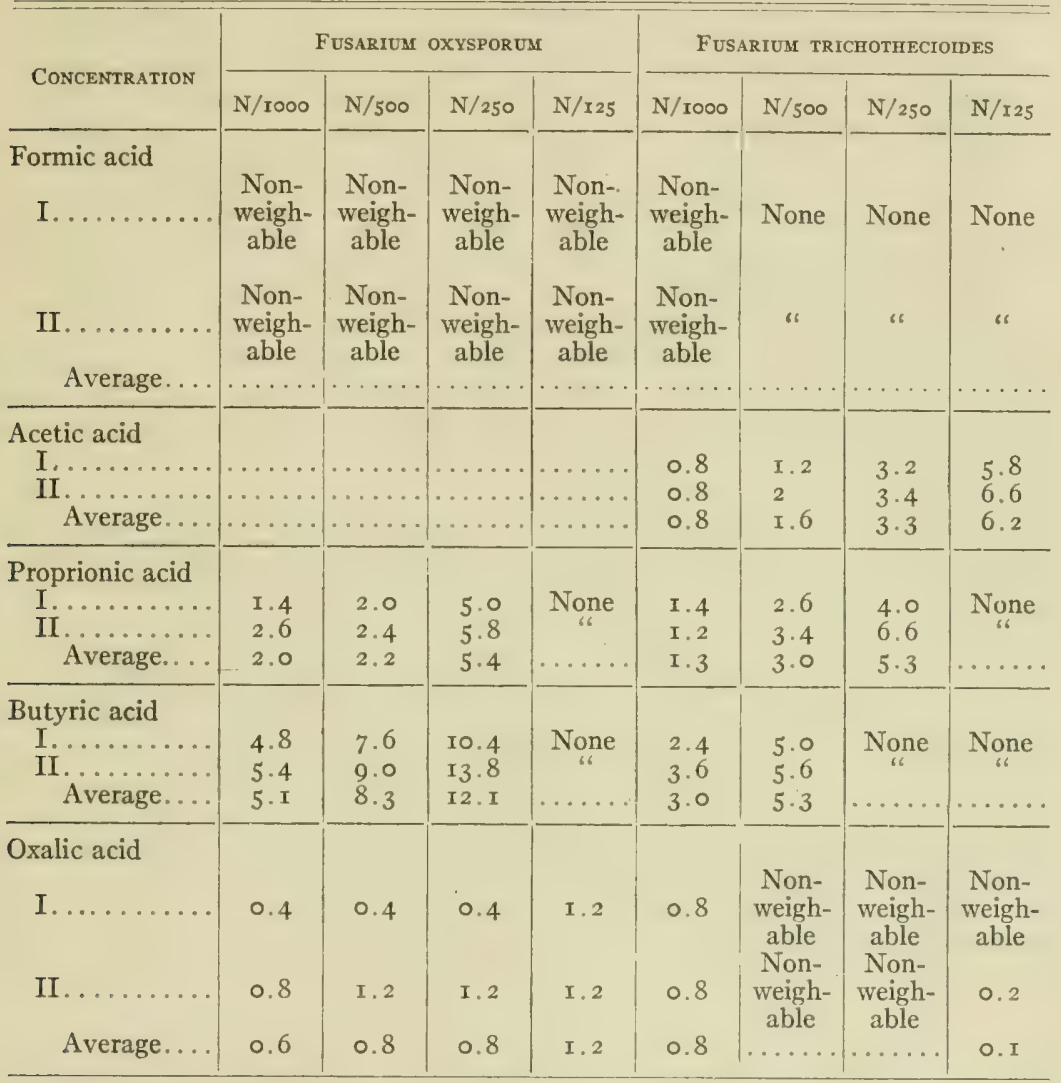

A set of experiments was run also in which solanin in various percentages was added to glucose media. Because of the high cost of solanin, only I cc. solution was used in each test. The results are given in table $\mathrm{X}$.

These differences, that is, greater versatility in the use of carbon sources, greater resistance to inhibition, and intoxication, may well 
play an important rôle in determining the difference in behavior of these two organisms.

TABLE X

DRY WEIGHT (IN MILLIGRAMS) FORMED BY Fusarium oxysporum AND F. trichothecioides IN 6 DAYS

\begin{tabular}{|c|c|c|c|c|c|}
\hline & \multicolumn{5}{|c|}{ Percentage solanin } \\
\hline & I & 2 & 0.25 & 0.226 & ○ \\
\hline $\begin{array}{l}\text { Fusarium oxysporum.... } \\
\text { Fusarium trichothecioides }\end{array}$ & $\begin{array}{r}10.6 \\
2.5\end{array}$ & $\begin{array}{l}8 . I \\
2.4\end{array}$ & $\begin{array}{r}13.2 \\
7.8\end{array}$ & Io & $\begin{array}{r}\text { I3.8 } \\
9.3\end{array}$ \\
\hline
\end{tabular}

Discussion.-The versatility of these organisms in using various carbon sources in their metabolism is of great interest. This almost omnivorous ability to use carbon compounds, including the simplest fatty acid, the highly oxidized fatty acids, the long carbon chain acids, the alcohols, mono- and poly-hybic, glycerin and fats, the mono-, di-, and poly-saccharides, including the dextrines, starches, hemicelluloses, and true celluloses, assigns to them an important rôle in the carbon cycle, and at the same time must help render them the formidable and destructive enemies of the root crops that they are.

The methods suggested by Appex (2), namely, rigid inspection of potato fields, immediate destruction of all plants that show the slightest symptoms, quarantining of non-certified seed stock, alone give promise of keeping these troubles in check. Disinfection of storage cellars and of potatoes when put into storage, together with storage at proper temperature, will help combat these diseases, especially the dry rot induced by $F$. trichothecioides.

\section{Conclusions}

r. Fusarium tuberivorum Wilcox and Link is the same as Fusarium trichothecioides Woll.

2. Both Fusarium oxysporum and F. trichothecioides can produce both tuber rot and wilt of the potato plant.

3. The wilt is induced by destruction of the root system and by clogging of the xylem elements in the stem, and is, in mild cases, marked by such symptoms as discoloration of leaves, curling and rolling of leaves, and production of aerial tubers. 
4. Under field and storage conditions Fusarium oxysporum is more probably responsible for wilt than is $F$. trichothecioides, and the latter more responsible for tuber rotting.

5. The optimum and maximum temperatures of Fusarium oxysporum are higher than those of $F$. trichothecioides. F. trichothecioides, however, 'grows well at 8-10 $\mathrm{C}$., while $F$. oxysporum does not. These facts may explain in part the fact that $F$. oxysporum produces more wilt than $F$. trichothecioides, and that the latter causes more tuber rot.

6. Fusarium oxysporum has a more rapid, superficial, and spreading habit of growth than has $F$. trichothecioides. This may be associated with a greater oxygen requirement for $F$. oxysporum, and may account for the frequenting of xylem elements by this fungus.

7. Both organisms possess a striking ability to use the most diverse carbon materials as carbon sources in their metabolism. Fusarium oxysporum has a greater range in its ability, and can utilize the materials more readily, although not so completely as does $F$. trichothecioides.

8. Fusarium oxysporum is less subject to inhibition in growth and intoxication than is $F$. trichothecioides.

9. Solanin is not toxic to either organism, although it seems to inhibit somewhat the growth of Fusarium trichothecioides.

The writer acknowledges his indebtedness to Dr. E. MEAD Wilcox and to Dr. William Crocker. They not only made this research possible, but they gave freely of advice and criticism, and lent encouragement by their interest in the progress of the investigation.

Agricultural Experiment Station

University OF Nebraska

\section{LITERATURE CITED}

I. ApPer, Otтo, Untersuchungen über die Schwarzbeinigkeit und die durch Bakterien hervorgerufene Knollenfäule der Kartoffel. Arb. Biol. Abth. Land- u. Forstw. Kais. Gesund. 3:362-432. pl. I. figs. I-I5. I903.

2. - Leaf roll diseases of the potato. Phytopathology 5:I39-I48. I9I5. 
3. Appel, O., and Kreitz, Wilhelm, Untersuchungen über die Schale verschiedener Kartoffelsorten und ihre Beeinflussung durch Bodenverhältnisse, Feuchtigkeit und Düngung. Arb. Kais. Biol. Anst. Land- u. Forstw. 6:I-27. pls. 2. figs. I-IO. I908.

4. Appel, O., and Schlumberger, Otto, Die Blattroll Krankheit und unsere Kartoffelernten. Berlin. pp. I02. pls.3. I9II. This contains a complete bibliography.

5. Appel, O., and Wollenweber, H. W., Grundlagen einer Monographie der Gattung Fusarium (Link). Arb. Kais. Biol. Anst. Land- u. Forstw. 8: I-207. pls. 4. figs, I-2. I9Io.

6. BARY, A. DE, Die gegenwärtig-herrschende Kartoffelkrankheit, ihre Ursache, und ihre Verhütung. Eine pflanzenphysiologische Untersuchung in allgemein verständlicher Form dargestellt. Leipzig. pp. 755. I86I.

7. Carpenter, C. W., Some potato tuber-rots caused by species of Fusarium. Jour. Agric. Research. Dept. Agric. 5:no. I5. 183-209. pls. 7 . I91 5.

8. Corsault, J. H., Studies of the Rhizoctonia disease of potatoes. Phytopathology 5:293-294. I915.

9. Drayton, F. L., The Rhizoctonia lesions on potato stems. Phytopathology 5:59-63. pl. I. fig. $x$. I9I5.

ro. Duggar, B. M., Fungous diseases of plants, with chapters on physiology, culture methods, and technique. Boston. I909.

Ir. Frank, A. B., Die Krankheiten der Pflanzen. Breslau. I896.

12. — Untersuchungen über die verschiedenen Erreger der Kartoffelfäule. Ber. Deutsch. Bot. Gesells. r6:273-280. I898.

13. Gloyer, W. O., The efficiency of formaldehyde in the treatment of seed potatoes for Rhizoctonia. Bull. no. 370. N.Y. Exp. Sta. 4I7-43I. I9I3.

14. Hasselbring, The carbon assimilation of Penicillium. Bот. Gaz. 45: I76193. 1908.

I5. HUMPhREy, H. B., Studies on the relation of certain species of Fusarium to the tomato blight of the Pacific Northwest. Bull. State Coll. Wash. Agric. Exp. Sta. no. II 5. pp. 21; pls. 5. I9I4:

r6. Jamieson, C. O., and WollenWeber, H. W., An external dry rot of potato tubers caused by Fusarium trichothecioides Wollenw. Jour. Wash: Acad. Sci. 3:I46-I52. fig. I. I9I2.

r7. Jones, L. R., Potato diseases in Wisconsin and their control. Circ. of Information. Wis. Exp. Sta. 36: I-IO. I9I2.

18. Lindau, G., Die pflanzlichen Parasiten. Sorauer's Hand. d. Pflanzenkr. 2:pp. 550. figs. 62. I908.

I9. LINK, GEo. K. K., Studies of a Fusarium causing dry rot of Irish potatoes. Thesis, Univ. of Neb. May Igr2.

20. LINK, H. F., Observationes in ordines plantarum naturales. Mag. Gesells. Naturf. Freunde 2:3-42. I809.

21. - Species Hyphomyceten et Gymnocetum. Pars I. I824. 
22. Longman, Sibyl, The dry rot of potatoes. Jour. Linn. Soc. Bot. 39: I 20-I29. pl. I. I909.

23. Lounsbury, C. P., Dry rot of the potato. Agric. Jour. Cape Good Hope 35:42-48. figs. 3I. I909.

24. Manns, Thos. F., The Fusarium blight and dry rot of the potato. Bull. no. 229. Ohio Exp. Sta. 299-336. pls. I-I5. I9II.

25. Massee, G., Textbook of plant diseases. London. rgo4.

26. Morse, W. J., and Schapovalov, M., The Rhizoctonia disease of potatoes. Bull. no. 230. Maine Exp. Sta. I9I4.

27. Orton, W. A., Potato wilt, leaf roll, and related diseases. Bull. no. 64 . U.S. Dept. Agric. pp. 49. pls. I6. I9I4.

28. Pethybridge, G. H., and Bowers, G. E. H., Dry rot of the potato tuber. Econ. Proc. Roy. Dublin Soc. I: 547-558. pl. 48. I908.

29. Pizzigoni, A., Cancrena secca ed unida delle patate. Nuovo Giov. Bot. Ital. 3:50-53. I896.

3o. Reinke, J., and Bertholdt, G., Die Zersetzung der Kartoffel durch Pilze. Untersuch. Bot. Lab. Univ. Göttingen, Berlin. I879.

31. Rolfs, F. M., Potato failures. A preliminary report. Bull. no. 70. Coll. Agric. Exp. Sta. pp. I9. pls. I2. I902.

32. — Potato failures. A second report. Bull. no. 9I. Coll. Agric. Exp. Sta. pp. 33. pls. 5. I904.

33. Sherbakoff, C. D., Fusaria of potatoes. Memoir. Cornell Univ. Agric. Exp. Sta. 6:90-270. pls. 7. I9I5.

34. Sмгтн, E. F., Wilt disease of cotton, watermelon, and cowpea (Neocosmospora, n. gen.). Bull. U.S. Dept. Agric. Div. Veg. Phys. and Path. I7: I-26. pls. IO. I899.

35. Smith, E. F., and Swingle, D. B., Dry rot of potatoes due to Fusarium oxysporum. Bull. no. 55. Bur. Pl. Ind. U.S. Dept. Agric. pp. 64. pls. 8. figs. 2. 1904 .

36. Sorauer, Paul, Pflanzenkrankheiten. Berlin. I886.

37. Stewart, F. G., and Gloyer, W. O., The injurious effect of formaldehyde gas on potato tubers. Bull. no. 369. N.Y. Agric. Exp. Sta. 385-4I6. pls. 3. $\mathrm{r} 9 \mathrm{I} 3$.

38. Wehmer, C., Über die Ursache der sogenannten "Trockenfäule" der Kartoffelknollen. Ber. Deutsch. Bot. Gesells. I4:I0I-I07. figs. 3. I896.

39. —- Ansteckungsversuche mit Fusarium Solani (Die Fusarium Fäule). Centralbl. Bakt. u. Par. 3:727-743. pls. Io, II. I897.

40. Wilcox, E. M., Link, Geo. K. K., and Pool, V. W., A dry rot of the Irish potato tuber. Research Bull. Neb. Agric. Exp. Sta. I: pp. 88. pls. 28. I9I3.

41. Wollenweber, H. W., Studies on the Fusarium problem. Phytopathology 3:24-50. pls. 5. fig. I. I9I3.

42. - Pilzparasitäre Welke-Krankheiten der Kulturpflanzen. Ber. Deutsch. Bot. Gesells. 31:17-34. I9I3. 

$x$

\section{$-$}

\section{a}


LIBRARY OF CONGRESS

"1.

00214682989 